\title{
Impact of Foreign Direct Investment on the Financial Performance of Listed Deposit Banks in Nigeria
}

\author{
Tony Ikechukwu Nwanji ${ }^{1}$, Kerry E. Howell ${ }^{2}$, Sainey Faye $^{3}$, Adegbola Olubukola Otekunrin ${ }^{1}$, Damilola Felix \\ Eluyela $1^{1}$, Adedoyin Isola Lawal ${ }^{1} \&$ Sunday Chinedu Eze ${ }^{4}$ \\ ${ }^{1}$ Department of Accounting and Finance, Landmark University, Nigeria \\ ${ }^{2}$ Teesside University Business School, Teesside University, UK \\ ${ }^{3}$ School of Business, Law and Computing. Buckinghamshire New University, UK \\ ${ }^{4}$ Department of Business Administration, Landmark University, Nigeria \\ Correspondence: Damilola Felix Eluyela, Department of Accounting and Finance, Landmark University, Nigeria.
}

Received: August 30, 2019

doi:10.5430/ijfr.v11n2p323
Accepted: November 29, 2019

Online Published: March 17, 2020

URL: https://doi.org/10.5430/ijfr.v11n2p323

\begin{abstract}
In this study, we examine the impact of foreign direct investment (FDI) on the financial performance of Nigerian listed deposit banks. We collected secondary data from the annual reports and accounts of 14 banks between 2010 and 2017. We employed the Tobin Q quantitative method for the analysis. We adopted the theoretical framework of pecking order theory since the analysis of the impact of FDI on the financial performance of these banks are both inward and outward FDI. The Tobin Q method was used as the dependent variable and FDI as an independent variable. Board size, firm size, equity capital and reinvested earnings were all financial performance indicators employed to test the impact of FDI on the financial performance of the banks on understudy in Nigeria. The result of the data analysis and findings showed that FDI had contributed positively to the development and performance of the deposit banks over the period under consideration. Our theoretical findings suggest a positive relationship between FDI and profit maximization. This support the FDI theory that banks or organisations are financed partly with debt-equity, both used by the banks to balance the cost and benefit financing decisions by the management. In the case of the empirical findings, the results of hypothesis testing show a significant effect on the banks' financial performances. Given these results, we conclude that FDI has made a positive impact on the development and financial performances of the listed deposit banks under study which resulted in some of the banks' growth from local banks in Nigeria into some of the leading international banks in Africa.
\end{abstract}

Keywords: business, corporate governance, exchange rate, financial performance, foreign direct investment, foreign equity capital, reinvested foreign earning, Tobin Q

\section{Introduction}

This study is based on the impact of foreign direct investment in the financial performance of listed deposit banks in Nigeria. Foreign direct investment (FDI) is essential in the banking sector, and it is an investment which investors from other countries invest or set up in another country's business and the foreign investor as a legal right or control on the company profit. In this study, we examine the impact of foreign direct investment in the financial performance of listed deposit money banks in Nigeria. All the deposit money banks are listed on the Nigerian Stock Exchange. Data for the study was acquired from banks from the annual reports of the banks published on the Nigerian Stock Exchange covering the periods of research was seven years, 2010 to 2017. The reason for selecting those years is to capture the trend and have more robust information about the financial activities of banks under study. The data collected was analysed using quantitative research methods. We adored the Tobin Q method of analysis to test the impact of FDI and the Financial Performance listed banks in the Nigerian Stock Exchange Market (Okere et al, 2019). This observation made that the inadequate corporate framework does not only lead to poor financial performance and risky financing strategy but has also led to various macroeconomic crises such as the East Asia crisis of 1997, the global financial meltdown of 2008 -2009 and Nigerian Financial Services Sector in 2010 - 2011. (Bello \& Adeniyi, 2010; Eluyela et al., 2018a; Olumuyiwa \& Oluwatosin, 2012; Umaru et al., 2015; Uwuigbe et al., 2018). 
Balsuburamanyan, and Salisu, (2010), defined foreign direct investment as one of the inputs which have to do with labour and capital. The author said that FDI is one of the primary forces driving economic development in an undeveloped country. FDI is the primary source of technology transfer as well as financial and workforce development to the receiving country and differentiates itself from another investment form in the states. Thirlwall (1994) refer to foreign direct investment as an investment of multinational companies or organization in developing countries. This investment does not only involve the transfer of funds, but it also includes a whole package of physical capital, techniques of production, managerial and marketing ability, product advertising and business practice for the maximization of global profits (Oji-Okoro et al., 2014).

Financial performance has been perceived only through its ability to yield a profit; this view seen for a long time (Akintimehin et al, 2019; Otekunrin et al, 2018). The concept of financial performance is dependent on the users' perspective. Therefore, financial performance is not only seen through its ability to yield returns but as its user defines it. Aminu et al. (2015) studied the effects of board size and board composition on the performance of Nigerian banks, using the financial statements of five banks over nine years' period. The authors employed multivariate regression analysis and found that board size has a significant negative impact on the performance of banks in Nigeria (2015). (Adeniyi et al., 2012), Those studies can be grouped into two categories: Firstly, are studies that focused on the FDI and financial performance across countries and secondly, studies that focused on the FDI and financial performance in a country. Amos (2016) work on the effect of foreign direct investment on the performance of the banking sector in Ghana. While Korna et al., 2013) carried out a study on the impact of foreign direct investment on bank performance in Nigeria. Chee and Nair, (2010), research foreign direct investment and financial sector development (Festus, 2018; Hossain, 2015; Eluyela et al., 2019).

\subsection{Research Objectives}

The main aims of the research are to study the impact of foreign direct investment in the financial performance of the listed Nigerian deposit money banks.

The specific aims are to:

* To examine the meaningful relationship between reinvested foreign earnings and financial performance of deposit money banks in Nigeria.

* To assess whether foreign equity capital has a significant impact on financial performance of deposit money banks in Nigeria.

* To determine the significant impact of board size on financial performance of deposit money banks in Nigeria.

* To examine the meaningful relationship between firm size and financial performance of deposit money banks in Nigeria.

\subsection{Research Questions}

The research question planned to be used to gain the aims of this research work.

* How does foreign Direct Investment affect the financial performance banks in Nigeria?

* What is the impact of Foreign equity capital equity on Nigerian banks' financial performance?

* Does Board Size have a significant impact on the financial performance of Nigerian banks?

* What is the relationship between firm size and financial performance of deposit money banks in Nigeria?

\subsection{Research Hypothesis}

To answer the research questions raised above, the following hypothesis will be tested in the later section of this research work. These are:

\subsubsection{Hypothesis (1)}

H0: There is no relationship between foreign direct investment and the financial performance banks in Nigeria.

H1: There is a relationship between foreign direct investment and financial performance of banks in Nigeria.

\subsubsection{Hypothesis (2)}

H0: Foreign equity capital does not have a significant impact on Nigerian banks' financial performance

H1: Foreign equity capital has a significant impact on Nigerian banks' financial performance. 


\subsubsection{Hypothesis (3)}

H0: Board Size does not have a significant impact on the financial performance of Nigerian deposit money banks.

H1: Board Size has a significant impact on the financial performance of Nigerian deposit money banks.

\subsubsection{Hypothesis (4)}

H0: There is no meaningful relationship between firm size and financial performance of banks in Nigeria.

H1: There is a meaningful relationship between firm size and financial performance of banks in Nigeria.

\section{Literature Review}

In the literature review, we outline the impact of foreign direct investment in the development of the world economy and particularly the developing and emerging economy such as in Nigeria. Foreign direct investment has been proved in the literature to be an essential promoter of growth. Research on foreign direct investment (FDI) showed that it increases the level of domestic capital formation; this also implies producing on a large scale, which in turn results in benefits of economies of scale, specialisation, increasing export and employment opportunities, which are likely to result in positive economic impact (Olumuyiwa \& Oluwatosin 2012). Bende-Nabende, (2002: 2), defines foreign direct investment as

"Financial outlays for the acquisition of an existing enterprise either through direct purchase or through purchases of equity, with a controlling interest of the foreign investor and with the notion of control is not defined but control is assumed when the foreign investor owns at least $10 \%$ to $51 \%$ of the enterprise's value according to different definitions used by different governments"

FDI is a crucial ingredient of successful economic growth in developing countries because the very essence of economic development is the rapid and efficient transfer and cross border adoption of best practices, be it managerial and technical best practice or deployment of technology from abroad (Borensztein et al., 1998). According to Olumuyiwa and Oluwatosin, (2012), FDI has also been argued to act as a catalyst for inward investment by complementing local resources and supplying a signal of confidence in investment opportunities (Agosin \& Mayer, 2000; Idoko et al., 2015). Luiz and Mello (1999), stated that there is conflicting evidence in the literature regarding the question as to how, and to what extent, Foreign direct investment affects economic growth. Other studies include: (Al-Iriani \& Al-Shamsi, 2007; Onyekwena, 2012; Ahmed \& Omorose, 2016).

\subsection{Conceptual Framework}

According to Thirlwall (1994), foreign direct investment refers to investment by multinational companies with headquarters in developed countries. This investment involves not only a transfer of funds (including the reinvestment of profits) but also a whole package of physical capital, techniques of production, managerial and marketing ability, products advertising, and business practices for the maximization of global profits. Other studies in this area include: (Asafo-Adjei, 2007; Mukolu et al., 2013; Okaro, 2016; Akanegbu \& Chizea, 2017; Elar, 2018).

Amondi, (2017:3), suggested that;

"FDI also differs in their objective aboard; they can be resource seeking, efficiency-seeking and market seeking. Resource seeking is concerned with moving their operations close to the resources, efficiency-seeking is concerned with cutting costs, and market seeking are concerned with the market for its products" (Nunnenkamp, and Spatz 2004).

\subsubsection{Foreign Direct Investment in the Banking Sector in Nigeria}

Foreign direct investment (FDI) was recognised as a powerful engine for economic growth; it did not only serve the long-term commercial interests of foreign investors but can also play a significant role in the growth dynamics of host countries (Jonida, 2015). The Nigeria government had in the past endeavoured to provide foreign investors with a healthy climate as well as generous tax incentives within the banking and financial sector, but the result has not been sufficiently encouraging in the past. Nigeria still required foreign aids in the form of managerial and technical skills. FDI represents control of production as well as a flow of capital, and it is influenced by other factors as well in the banking sector. In the traditional trade approach, trade and FDI might be substituted, but other factors affect FDI, such as technology and firm-specific assets (Markusen, 1984; Markusen \& Venables, 1998; Danja, 2012). The first attempts were by Elhanan, (1984), who integrated vertical multinationals. Markusen (1984), integrated horizontal multinationals into the trade theory. On this view, African outward FDI (particularly intra-Africa banking system) will grow, but only in the future as incomes in Africa rise and their economic structures become similar. Other 
studies on FDI in the banking sector and economic growth in Nigeria include: (Akinlo, 2004; Ajayi, 2006; Ayanwale, 2007; Eluyela et al., 2018b; Olokoyo, 2012; Okonkwo et al., 2015; John, 2016; Aguda \& Oladoja, 2017).

\subsubsection{Types of Foreign Direct Investment}

Borensztein et al. (1998:117) defined FDI as:

"an investment made to acquire a long-term investment in a foreign enterprise with the view of having a voice in the enterprise's management. FDI can take three forms horizontal foreign direct investment which occurs when a company undertakes the same activities aboard as at home, vertical foreign direct investment where different stages of activities are added aboard and platform foreign direct investment: conglomerate where a company expands its operations aboard through either greenfield or acquisition."

The three main types of foreign direct investment defined above by Borensztein et al. (1998), can be represented in Diagram A below: (i) platform foreign direct investment (ii) horizontal foreign direct investment and (ii) vertical foreign direct investment

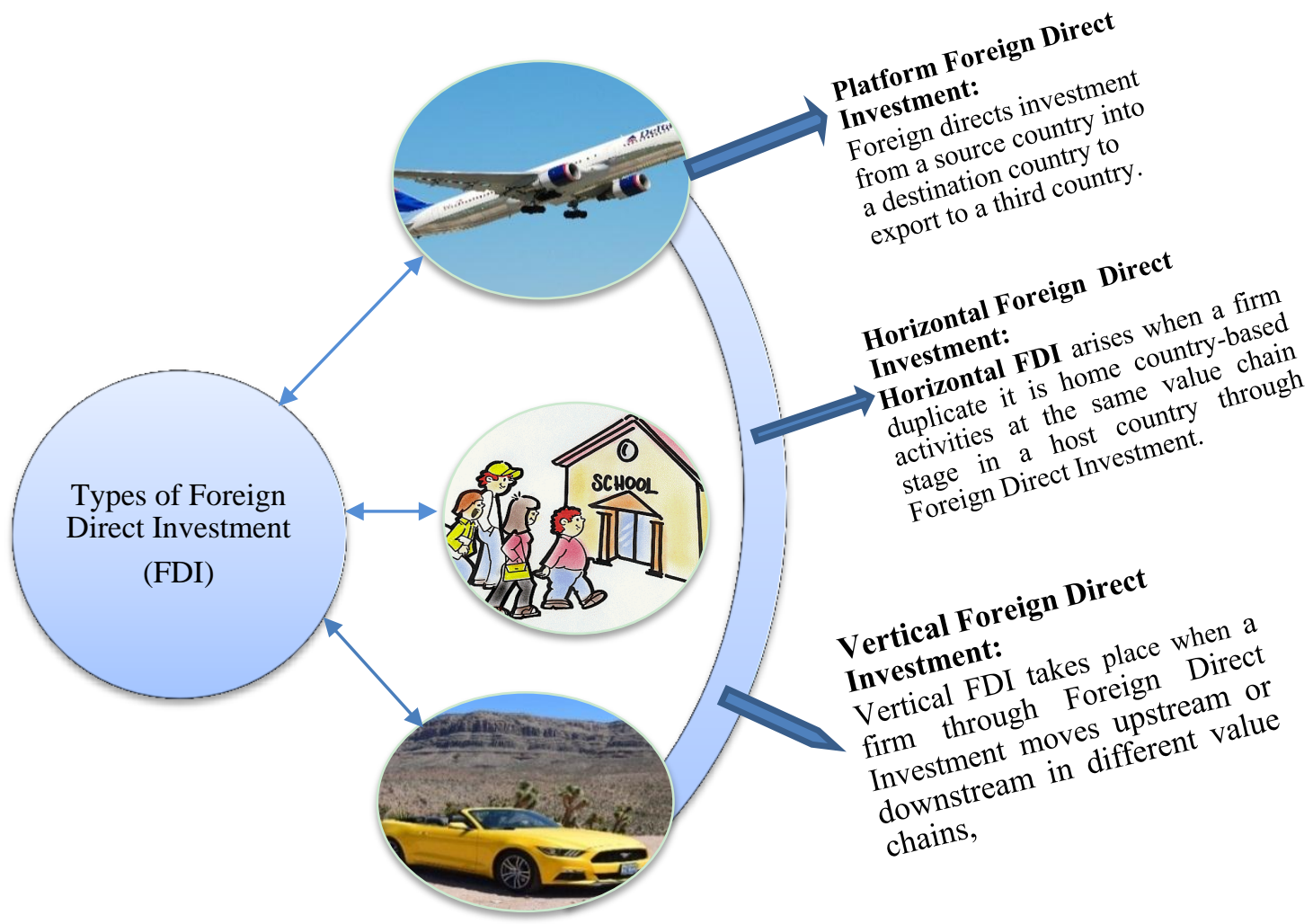

Diagram A. Types of foreign direct investment

Source: Authors' compilation (2019)

\subsubsection{Summarised are the Four Propositions of FDI}

a) That FDI tends to boost domestic investment in Nigeria.

b) The mining and quarrying and the manufacturing sectors have not been able to justify the sizeable foreign capital they have received over the years.

c) That the agricultural sector has not contributed meaningfully to GDP, and it is the least sector in the economy that attracts FDI inflow. 
d) That, of all the sectors under review, the telecom sector is the only sector that to a considerable extent, have been significantly affected by FDI, especially in recent times. (Borensztein, et al., 1998; Bjorvatn, 2000; Bjorvatn et al. 2002; O'Connor et al., 2013).

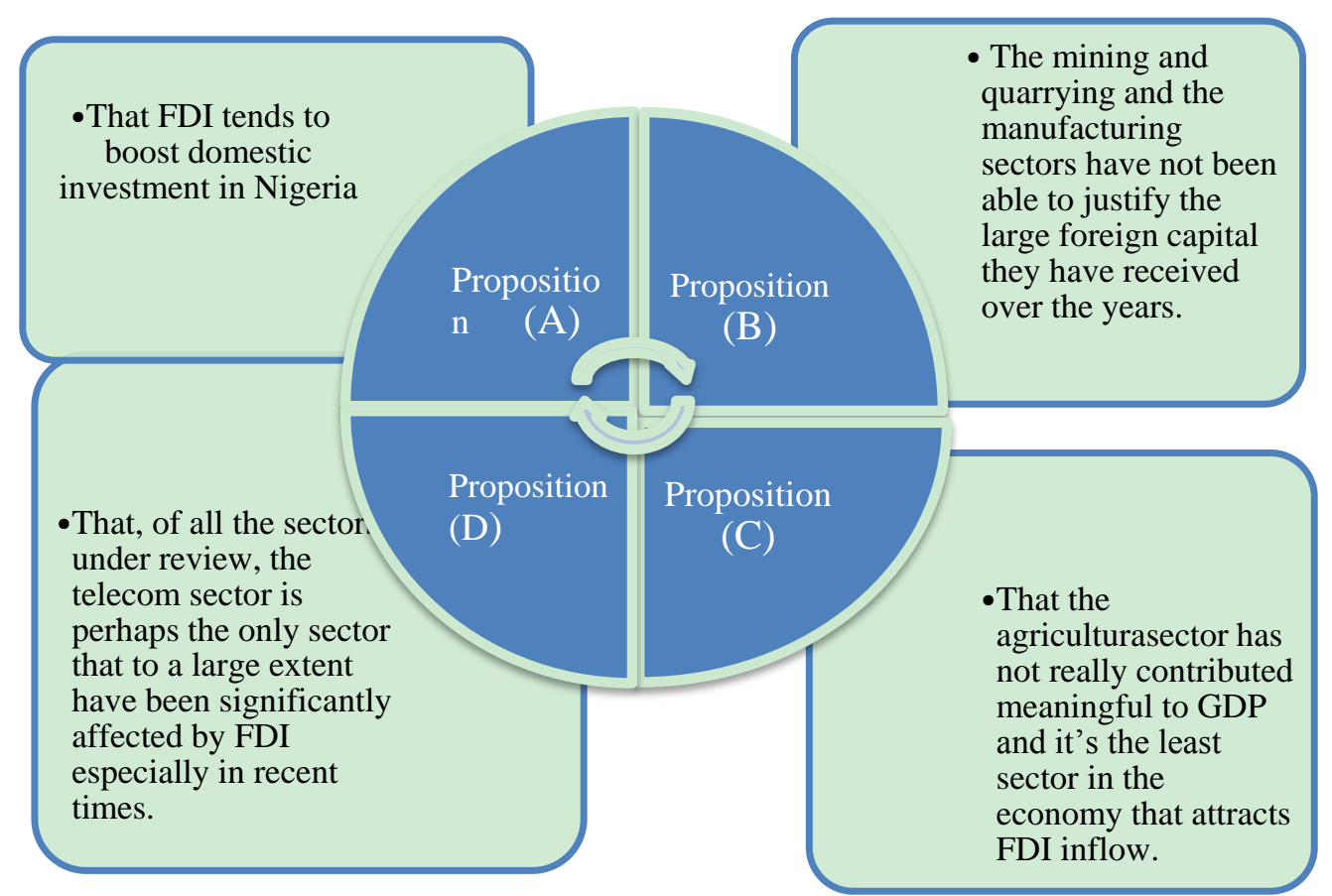

Diagram B. Four propositions of FDI: this is the four propositions of foreign direct investment in the banking sector Source: Authors' compilation (2019)

\subsection{Theoretical Framework}

Foreign direct investment (FDI) can be defined as the financed by a loan obtained in a host country, payments in exchange for equity (patents, technology, machinery etc.), and other methods. Neo-classical researchers regard FDI, and international capital flows as closing the savings gap in developing countries (e.g. Hollis \& Bruno, 1962; Dornbusch \& Edward, 1990; Danja, 2012). We would expect capital to flow from productive capital to poor capital countries, as is recommended by developments in the Heckscher-Ohlin approach to trade by Robert (1957). This is so because capital is scarce in developing countries, which should lead to profitable investment opportunities for wealth in developing countries. On this view, there should be no outflows from Africa (Goldberg \& Klein, 1998, 1999; Ikon \& Chika, 2019; Aluko, 1961; Brown, 1962; Blomström, 1986; Asaleye et al., 2018).

The main determinants of FDI on the growth prospects of the Nigerian listed deposit banks take the form of firm-specific advantages, removal of conflicts and propensity to formulate an internationalization strategy to mitigate risk: The three theoretical frameworks adopted by researchers in relation to FDI and business and financial performance in the banking and financial sector include the following theories:

\section{* Pecking Order Theory, \\ * Trade-off Theory and \\ * Profit Maximization Theory}

In this research study, we adopted the pecking order theory propounded by Myers and Majluf (1984), which says that; managers are given the hierarchy to follow the source of finance. The causes of funding are the internal source and external source. The theory argues that an internal source of finance is preferable than the external source of financing, use the debt instead of equity because the cost of debt is lower than the cost of capital. This theory argues 
that the irregularity of information disturbs the firm's (in this case the bank's) value which affects the wealth bank's shareholders (Hennart, 1982; Nwanji \& Howell, 2007b; Salazer, et al., 2012; Aigner et al. 2013; Cyree \& Morris, 2018; Wong, 2012; Qureshi et al., 2015). The factors that lead to a higher cost of capital include a lack of relevant information on the value of capital available to investors at the time of the investment (Wong, 2012; Qureshi et al., 2015). This is a process that a company undergoes to determine the best output and price levels to maximise its return. The two models of the trade-off theory are the Marginal Cost-Marginal Revenue method and the Total Cost-Total Revenue Methods. The approach is based on the argument that the primary goal of an organisation is to maximise profit. Studies in this area include but not limited to that of (Modigliani \& Miller, 1963; Helpman, 1998; Childers et al., 2001; Dasgupta, 2009).

\subsubsection{Equity Capital and Bank Performance}

This is where a corporation finances its assets through some combination of debt, hybrid Securities; that is the combination of both equity and debt. Capital structure is a combination of equity and debt. Investment is the value of an asset less than the cost of all liabilities on the asset. Financial performance is the process of measuring the result of a firm.

Reinvested Earning and financial performance: What reinvested income means to potential investors. On a balance sheet or profit and statement, kept earnings appear as the part of the profit that stays after a company pays its taxes and issues dividends to its stockholders.

Intracompany loans and financial performance: Muchugia (2013) investigated that financing using debt affected the bank profitability and found that a positive relationship exists between short term debt (SDA) and profitability. This was because short term debt was cheaper and an increase in it, leads to a minimal increase in the interest rate leading to higher profits and better performance (Myers, 1977; Imoudu, 2012; Ajibola, e al 2018).

\subsection{Empirical Review}

Macaulay (2011) conducted a study on FDI and the performance of the Nigerian economy. The author claimed that view that FDI has a positive effect on Nigeria economic growth and its local industries. Ayanwale (2007) study on Foreign Direct Investment and economic growth in Nigerian, found out that FDI has a definite link with economic growth but cautioned that the overall effect of FDI on economic growth might not be significant. Other studies include: (Feng, 2008; Choong et al., 2004; Choong et al. 2005).

Onu (2012:5) also studied the impact of FDI on economic growth in Nigeria from 1986-2007. The author employed multiple regression techniques to determine the effects of FDI on the economic growth in Nigeria and concluded that; "FDI is the engine of economic growth and the great potentials of FDI for accelerating the pace of economic progress of Nigeria cannot be overemphasized because of the positive and significant impact should be allowed." Mahler (1989) carried out an analysis of 68 least developed countries and found a statistical association between income concentrated in the $6 \%$ and $20 \%$ of the population and foreign direct investment in manufacturing but not in mining and agriculture (King, et al., 1986; Haggard, 1989; Saad, 2014; Mahalakshmi et al., 2016; Barua et al. 2017; Desbordes, and Wei, 2017).

Osinubi and Amaghionyediwe (2010) research on the study of foreign private investment in real assets and international portfolio investment financial assets. The authors concluded that FDI intangible assets augment domestic resources and thus enhance economic growth since it gives a positive effect on growth issues it should not be ignored. Rodolphe and Shang (2017:153) study focused on the impact of financial development on foreign direct investment and found that; "FDI has an enormous positive influence on the Greenfield, mergers, acquisitions, and expansion. Foreign direct investment (FDI) promotes manufacturing activity directly and indirectly. He established causality by exploiting variations in both country financial development and sector financial vulnerability."

The research by Rafeal et al., (2017), on foreign direct investment and economic growth in Latin America, covering 19 Latin America countries. Using the panel data regression, the authors found that there is a significant and positive effect on product in high-income countries. It also shows that FDI is not an adequate instrument to hasten economic growth in Latin America. Nunnenkamp and Spatz (2004:54) researched the effect of foreign direct investment in the developed country and concluded that; "The growth impacts of FDI are uncertain because of highly aggregated FDI data. By disaggregating FDI and considering the compatibility of diverse types of FDI on economic conditions prevailing in the host country, the growth effects of FDI are not certain." Akinlo (2004) carried out research work on the impact of foreign direct investment (FDI) on economic growth in Nigeria using data from 1970 to 2001. The author's error correction model results showed that both private capital and lagged foreign capital have a small and insignificant impact on economic growth (Danja, 2012; Yusuf et al., 2014). This study proved positive and 
significant effects of export on growth. Economic development, which he measured as M2/GDP, has a significant negative impact on growth and attributed to capital flight. Other studies on FDI in Nigeria and selected African countries include: (Asogwa, 2014; Ayanwale \& Bamire, 2001; Bloomstrom, et al 2003; Chee \& Nair, 2010; Saddimbah, 2014; Bebeji, et al 2015; Umaru et al., 2015; Amondi 2017; Ananwude et al., 2018; Kariuki \& Sang, 2018; Iraya \& Sait, 2018; Anetor, 2019).

\section{Research Methodology}

For the study, we collected data from the banks under investigation based on their Annual Reports and Accounts for the periods from 2010 to 2017, published by the Nigerian Stock Exchange on its websites (Oladipo et al, 2019a). This method was to ensure that the information in the annual reports have been approved by the boards of each bank and met the requirements of both the Stock Exchange, the Corporate Governance Regulations, Corporate Law for Public Limited Companies. (PLC) moreover, the Banking Regulations in Nigeria. The quantitative research method used for this study is that of the Tobin Q Rate method, which equates the market value of a firm divided by its assets and replacement cost. Tobin's Q Ratio is a ratio developed by James Tobin, in 1968, a Nobel laureate in economics. Tobin theorized that the joint market value of all the firms on a stock market should be about equal to their replacement costs. It is said that if 'Tobin's Q' is more significant than one, then it means that the company is worth more than the value of its assets. In this case, added investment in the company's capital project would make sense because the returns incurred would exceed the cost of a firm's assets (Otokiti, 2010).

In this study if 'Tobin's Q' is less than one, it means that more cost is needed to replace a bank's assets than the bank is worth. Therefore, the bank would be better off selling its assets rather than trying to put them to use. For this study, we employed the Tobin's Q ratio for the analyses of data collected from the 14 deposit banks under consideration. Singh et al. (2017) reviewed Tobin's $Q$ ratio as a performance indicator and discovered it to be active and efficient. Tobin's Q ratio measures the market value of a firm compared to the value of the firm's assets (Chong et al., 2013; Nwanji et al. 2019).

\subsection{Model Specification}

In analyzing the information from the secondary data, panel data regression was used to test the independent and dependent variables. The independent variable is the foreign direct investment, (FDI), and the dependent variable is the Financial Performance of the deposit banks in Nigeria.

The model employed for data analyses

$$
\begin{gathered}
y=f(x) \\
F P=f(F D I) \\
F P=f(E C, R E)
\end{gathered}
$$

Add panel properties and control variables to equation (3) above:

$$
F P_{i t}=\beta_{0}+\beta_{1} E C_{i t}+\beta_{2} R E_{i t}+\beta_{3} F S I Z E_{i t}+\beta_{4} B S I Z E+\varepsilon_{i, t}
$$

Where;

$F P_{i t}=$ financial performance of sampled banks I at period $\mathrm{t}$

$E C_{i t}=$ equity capital

$R E_{i t}=$ reinvested earning

$F S I Z E_{i t}=$ firm size

$B S I Z E_{i t}=$ board size

$\beta_{0}=$ Coefficients of parameter

$\varepsilon_{i, t}=$ Error term

$i=$ Sampled firms

$t=$ time trend 
Table 1. Summary of the variable

\begin{tabular}{lll}
\hline Variable & Item & Measurement \\
\hline Dependent & Tobin Q & Total asset value+ Equity $\div$ Total asset value \\
\hline Independent & Foreign direct investment (FDI) & \\
\hline Control & Firm size (FSIZE) & $\begin{array}{l}\text { Amount of foreign equity capital (Shareholder } \\
\text { equity) }\end{array}$ \\
\hline Board size (BSIZE) & The total sum of the firm's asset \\
\hline
\end{tabular}

Source: Authors' compilation (2019)

\subsection{Apriori Expectation}

$\mathrm{B}_{1}>0$ : there is a significant positive relationship between equity capital and foreign direct investment.

$\mathrm{B}_{2}>0$ : there is a meaningful relationship between reinvested earnings and foreign direct investment.

$\mathrm{B}_{3}>0$ : there is a significant positive relationship between board size and foreign direct investment.

$\mathrm{B}_{4}>0$ : there is a meaningful relationship between firm size and foreign direct investment.

The data below in Table (2) relate to the banks understudy: Access Bank, Diamond Bank, Eco Bank, GTB, FCMB, First Bank, Fidelity Bank, Stanbic Bank, Skye/Polaris Bank, Sterling Bank, UBA, Union Bank, Unity Bank, Wema Bank, Zenith Bank for seven years (2010-2017).

Table 2. Annual reports of the banks listed in the Nigerian Stock Exchange

\begin{tabular}{|c|c|c|c|c|c|}
\hline Banks & TOBQ & EC & RE & FSIZE & BSIZE \\
\hline \multicolumn{6}{|c|}{ ACCESS } \\
\hline 2010 & 1.212 & $8,944,126$ & $7,666,913$ & 11.8921 & 14 \\
\hline 2011 & 1.208 & $8,944,126$ & $10,462,687$ & 11.8762 & 15 \\
\hline 2012 & 1.072 & $176,628,255$ & $18,880,711$ & 12.1806 & 15 \\
\hline 2013 & 1.133 & $172,477,671$ & $23,095,392$ & 12.2315 & 17 \\
\hline 2014 & 1.132 & $172,477,671$ & $36,499,779$ & 12.2971 & 17 \\
\hline 2015 & 1.142 & $212,438,802$ & $49,459,102$ & 12.3824 & 14 \\
\hline 2016 & 1.136 & $212,438,802$ & $93,329,188$ & 12.4907 & 14 \\
\hline 2017 & 1.134 & $212,438,802$ & $120,218,603$ & 12.5440 & 17 \\
\hline \multicolumn{6}{|c|}{ DIAMOND } \\
\hline 2010 & 1.106 & $7,237,622$ & $6,011,755$ & 11.8751 & 19 \\
\hline 2011 & 1.108 & $7,237,622$ & $(18,347,381)$ & 11.8537 & 19 \\
\hline 2012 & 1.092 & $7,237,622$ & $(6,851,491)$ & 12.0250 & 15 \\
\hline 2013 & 1.091 & $7,237,622$ & $18,439,851$ & 12.1319 & 14 \\
\hline 2014 & 1.108 & $11,580,195$ & $32,845,896$ & 12.2431 & 13 \\
\hline 2015 & 1.122 & $11,580,195$ & $12,208,773$ & 12.1918 & 12 \\
\hline 2016 & 1.111 & $11,580,195$ & $6,364,510$ & 12.2208 & 12 \\
\hline 2017 & 1.0127 & $11,580,195$ & $5,139,548$ & 12.2293 & 16 \\
\hline \multicolumn{6}{|l|}{ FCMB } \\
\hline 2010 & 1.196 & $8,135,596$ & $6,223,974$ & 11.7404 & 15 \\
\hline
\end{tabular}




\begin{tabular}{|c|c|c|c|c|c|}
\hline 2011 & 1.195 & $8,135,596$ & $(11,567,744)$ & 11.7731 & 15 \\
\hline 2012 & 1.145 & $9,520,534$ & $(360,864)$ & 11.9495 & 11 \\
\hline 2013 & 1.143 & $9,901,355$ & $6,027,752$ & 11.1189 & 11 \\
\hline 2014 & 1.137 & $9,901,355$ & $5,483,847$ & 11.1192 & 12 \\
\hline 2015 & 1.140 & $9,901,355$ & $3,056,244$ & 11.1119 & 12 \\
\hline 2016 & & $9,901,355$ & $4,806,213$ & 11.1185 & 14 \\
\hline 2017 & 1.985 & $9,901,355$ & $4,350,828$ & 11.1194 & 12 \\
\hline \multicolumn{6}{|c|}{ FIDELITY } \\
\hline 2010 & 1.202 & 14,481 & 5,606 & 11.8573 & 19 \\
\hline 2011 & 1.198 & 14,481 & 5,722 & 11.8680 & 19 \\
\hline 2012 & 1.177 & 14,481 & $(117)$ & 11.9611 & 17 \\
\hline 2013 & 1.151 & 14,481 & 7395 & 11.0339 & 7 \\
\hline 2014 & 1.146 & 14,481 & 11,721 & 11.0745 & 7 \\
\hline 2015 & 1.149 & 14,481 & 8,797 & 11.0905 & 4 \\
\hline 2016 & 1.143 & 14,481 & 25,918 & 11.1133 & 4 \\
\hline 2017 & 1.099 & 14,481 & 25326 & 11.1055 & 4 \\
\hline \multicolumn{6}{|c|}{ FIRST BANK } \\
\hline 2010 & 1.100 & 16,316 & 27,971 & 11.5429 & 16 \\
\hline 2011 & 1.129 & 16,316 & 53,144 & 11.4532 & 16 \\
\hline 2012 & 1.127 & 16,316 & 77,342 & 11.4956 & 8 \\
\hline 2013 & 1.102 & 16,316 & 37,180 & 11.5737 & 10 \\
\hline 2014 & 1.112 & 16,316 & 6,968 & 11.6161 & 10 \\
\hline 2015 & 1.127 & 16,316 & 130,787 & 11.5991 & 10 \\
\hline 2016 & 1.115 & 16,316 & 153,924 & 11.6546 & 10 \\
\hline 2017 & 1.972 & 17,948 & 10,104 & 10.6812 & 10 \\
\hline \multicolumn{6}{|c|}{ GTBANK } \\
\hline 2010 & 1.138 & $11,658,594$ & $21,465,320$ & 12.1614 & 14 \\
\hline 2011 & 1.154 & $14,715,590$ & $32,377,671$ & 12.1829 & 14 \\
\hline 2012 & 1.177 & $14,715,590$ & $47,558,325$ & 12.2096 & 14 \\
\hline 2013 & 1.170 & $14,715,590$ & $55,079,117$ & 12.2798 & 14 \\
\hline 2014 & 1.169 & $14,715,590$ & $58,442,378$ & 12.3277 & 14 \\
\hline 2015 & 1.178 & $14,715,590$ & $46,048,031$ & 12.3575 & 16 \\
\hline 2016 & 1.162 & $14,715,590$ & $83,989,499$ & 12.4172 & 16 \\
\hline 2017 & 1.207 & $14,715,590$ & $115,361,824$ & 12.4510 & 14 \\
\hline \multicolumn{6}{|c|}{ SKYE/POLARIS } \\
\hline 2010 & 1.110 & 5,792 & 10,644 & 11.9600 & 11 \\
\hline 2011 & 1.110 & 6,609 & 5,182 & 11.9428 & 12 \\
\hline 2012 & 1.097 & 6,609 & 12,697 & 9.0299 & 14 \\
\hline 2013 & 1.109 & 6,609 & 19,436 & 12.0469 & 13 \\
\hline 2014 & 1.102 & 6,609 & 32,225 & 12.0827 & 13 \\
\hline
\end{tabular}




\begin{tabular}{|c|c|c|c|c|c|}
\hline 2015 & 1.087 & 6,609 & $(17,134)$ & 12.0724 & 17 \\
\hline 2016 & 1.087 & 402,747 & 1,060 & 12.0790 & 17 \\
\hline 2017 & 1.341 & 402,747 & 1,060 & 12.0775 & 17 \\
\hline \multicolumn{6}{|c|}{ STANBIC } \\
\hline 2010 & 1.172 & 9,375 & 7,430 & 10.8751 & 13 \\
\hline 2011 & 1.153 & 9,375 & 3,559 & 10.8590 & 12 \\
\hline 2012 & 1.127 & 5,000 & 1,053 & 10.8604 & 12 \\
\hline 2013 & 1.133 & 592 & 8,332 & 10.8774 & 11 \\
\hline 2014 & 1.128 & 606 & 13,136 & 10.8789 & 7 \\
\hline 2015 & 1.138 & 5,000 & 9,871 & 10.8803 & 10 \\
\hline 2016 & 1.134 & 5,000 & 609 & 10.9678 & 12 \\
\hline 2017 & 1.952 & 5,025 & 25,165 & 10.9884 & 12 \\
\hline \multicolumn{6}{|c|}{ STERLING } \\
\hline 2010 & 1.084 & $6,281,545$ & $(2,036,115)$ & 11.6532 & 12 \\
\hline 2011 & 1.081 & $7,851,931$ & $2,644,416$ & 11.7052 & 113 \\
\hline 2012 & 1.080 & $7,851,931$ & $6,019,078$ & 11.7636 & 11 \\
\hline 2013 & 1.0897 & $10,796,497$ & $7,785,753$ & 10.8495 & 14 \\
\hline 2014 & 1.103 & $14,395,209$ & $5,753,977$ & 11.9162 & 14 \\
\hline 2015 & 1.120 & $14,395,209$ & $10.042,079$ & 11.9028 & 15 \\
\hline 2016 & 1.103 & 14,395 & 6,245 & 11.9321 & 15 \\
\hline 2017 & 1.096 & 14,395 & 8,238 & 11.9321 & 15 \\
\hline \multicolumn{6}{|l|}{ UBA } \\
\hline 2010 & 1.084 & 12,934 & 25,961 & 9.2229 & 20 \\
\hline 2011 & 1.079 & 16,168 & 8,289 & 11.0963 & 20 \\
\hline 2012 & 1.085 & 16,491 & 47,723 & 12.1832 & 25 \\
\hline 2013 & 1.089 & 16,491 & 67443 & 12.3458 & 16 \\
\hline 2014 & 1.096 & 16,491 & 84,230 & 12.3690 & 16 \\
\hline 2015 & 1.121 & 18,140 & 100,900 & 12.3456 & 16 \\
\hline 2016 & 1.128 & 18,140 & 110,152 & 12.4048 & 16 \\
\hline 2017 & 1.137 & 17,100 & 99,332 & 12.4671 & 16 \\
\hline \multicolumn{6}{|c|}{ UNION } \\
\hline 2010 & 1.191 & 6,755 & $(244,725)$ & 9.0107 & 12 \\
\hline 2011 & 1.189 & 8,468 & $(272,101)$ & 11.9176 & 14 \\
\hline 2012 & 1.188 & $4,979,791,1133$ & $285,042,347$ & 11.9176 & 13 \\
\hline 2013 & 1.199 & $4,979,791,1133$ & $203,207,583$ & 11.9455 & 17 \\
\hline 2014 & 1.220 & $16,334,781,723$ & $288,314,442$ & 11.9639 & 17 \\
\hline 2015 & 1.235 & $16,334,781,723$ & $467,692,147$ & 11.9992 & 17 \\
\hline 2016 & 1.217 & 400,109 & $(247,868)$ & 12.0506 & 16 \\
\hline 2017 & 1.241 & 201,652 & $(19,118)$ & 12.1255 & 20 \\
\hline
\end{tabular}




\begin{tabular}{|c|c|c|c|c|c|}
\hline 2010 & 1.113 & $16,643,588$ & $(14,267,186)$ & 11.5623 & 15 \\
\hline 2011 & 1.118 & $17,475,768$ & $(14,640,824)$ & 11.5727 & 17 \\
\hline 2012 & 1.130 & $17,475,768$ & $14,442,800$ & 11.5974 & 17 \\
\hline 2013 & 1.070 & $19,223,345$ & $(58,700,475)$ & 11.6060 & 18 \\
\hline 2014 & 1.185 & $58,446,690$ & $(56,434,482)$ & 11.6163 & 14 \\
\hline 2015 & 1.186 & $5,844,669$ & $(117,279,296)$ & 11.6467 & 14 \\
\hline 2016 & 1.175 & $5,844,669$ & $(275,980,402)$ & 11.6926 & 13 \\
\hline 2017 & 2.5475 & $5,844,669$ & $(338,694,712)$ & 11.6926 & 15 \\
\hline \multicolumn{6}{|c|}{ WEMA } \\
\hline 2010 & 1.026 & $6,410,623$ & $(27,359,631.4015)$ & 11.3222 & 10 \\
\hline 2011 & 1.028 & $6,410,623$ & $(35,475,856)$ & 11.3447 & 10 \\
\hline 2012 & 1.005 & $6,410,623$ & $(35,307,903)$ & 11.3904 & 12 \\
\hline 2013 & 1.125 & $19,287,233$ & $(35,184,210)$ & 11.5197 & 10 \\
\hline 2014 & 1.114 & $19,287,233$ & $(34,793,664)$ & 11.5827 & 12 \\
\hline 2015 & 1.116 & $19,287,233$ & $(35,319,223)$ & 11.5985 & 12 \\
\hline 2016 & 1.114 & $19,287,233$ & $(39,127,546)$ & 11.6245 & 12 \\
\hline 2017 & 1.129 & $19,287,233$ & $4,166,460$ & 11.5859 & 12 \\
\hline \multicolumn{6}{|c|}{ ZENITH } \\
\hline 2010 & 1.159 & 15,968 & 51,769 & 9.3424 & 12 \\
\hline 2011 & 1.169 & 15,698 & 55,028 & 9.3667 & 12 \\
\hline 2012 & 1.178 & 15,698 & 106,010 & 9.4157 & 14 \\
\hline 2013 & 1.162 & 15,698 & 126,678 & 12.4592 & 15 \\
\hline 2014 & 1.147 & 15,698 & 150,342 & 12.5345 & 12 \\
\hline 2015 & 1.148 & 15,698 & 160,408 & 12.5741 & 12 \\
\hline 2016 & 1.149 & 15,698 & 218,507 & 12.6318 & 11 \\
\hline 2017 & 1.147 & 15,698 & 296,787 & 12.6843 & 14 \\
\hline
\end{tabular}

Source: Authors' computation (2019) 


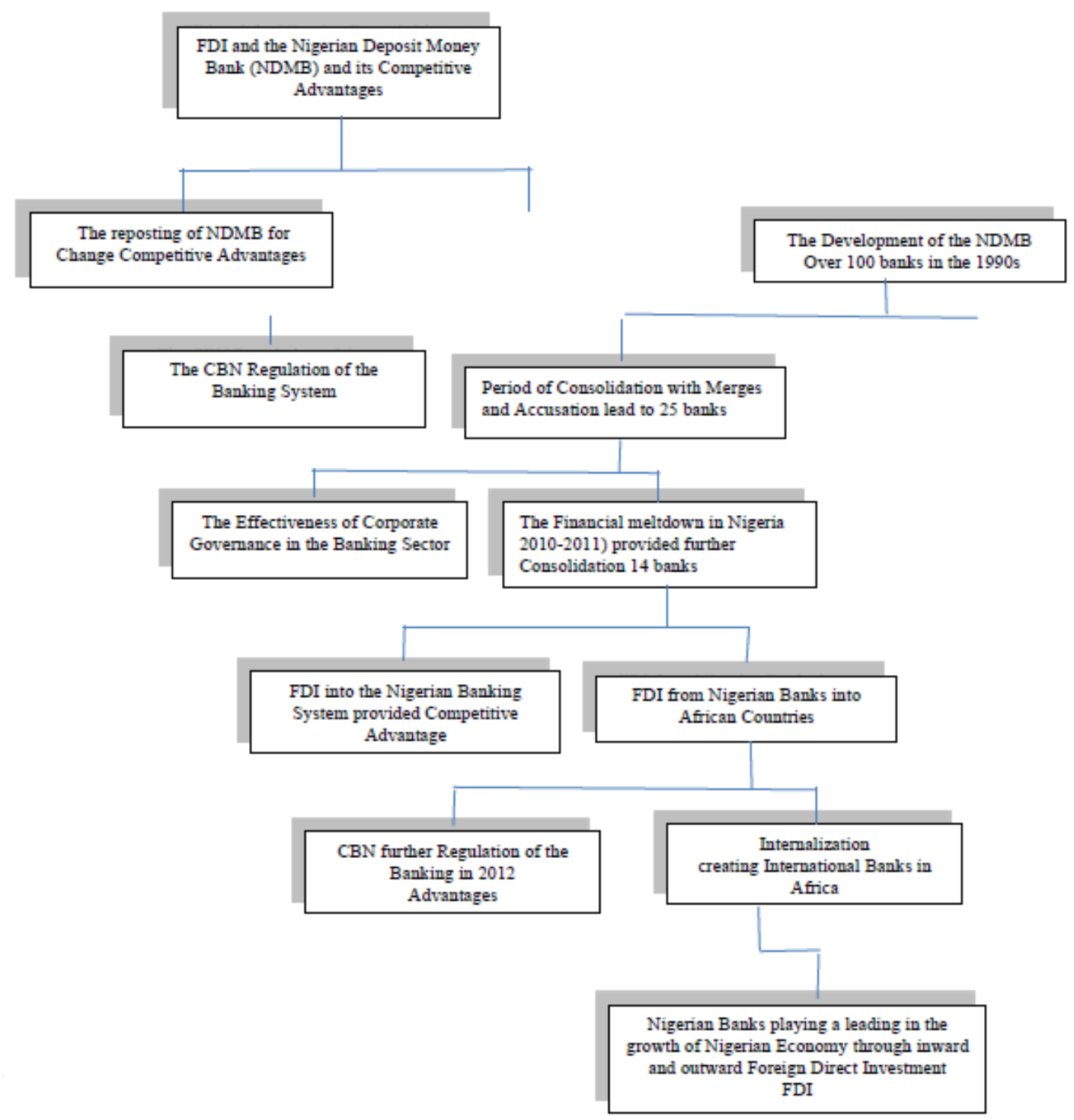

Diagram C. The competitive advantages of the Nigerian deposit money bank through FDI

Source: Authors' Computation (2019

\section{Data Presentation and Analysis}

This study examines foreign direct investment and financial performance of the listed deposit banks in Nigeria. In section, we deal with the presentation and analysis of the secondary data collected from the annual reports and of the banks from the Central Bank of Nigeria (CBN) website. A total of 14 annual reports from the CBN (2010) covering the periods from 2010 to 2017 were used, and information from the annual reports was analysed to the significant impact of equity capital on the financial performance of deposit money banks in Nigeria (Olabisi et al., 2016). 


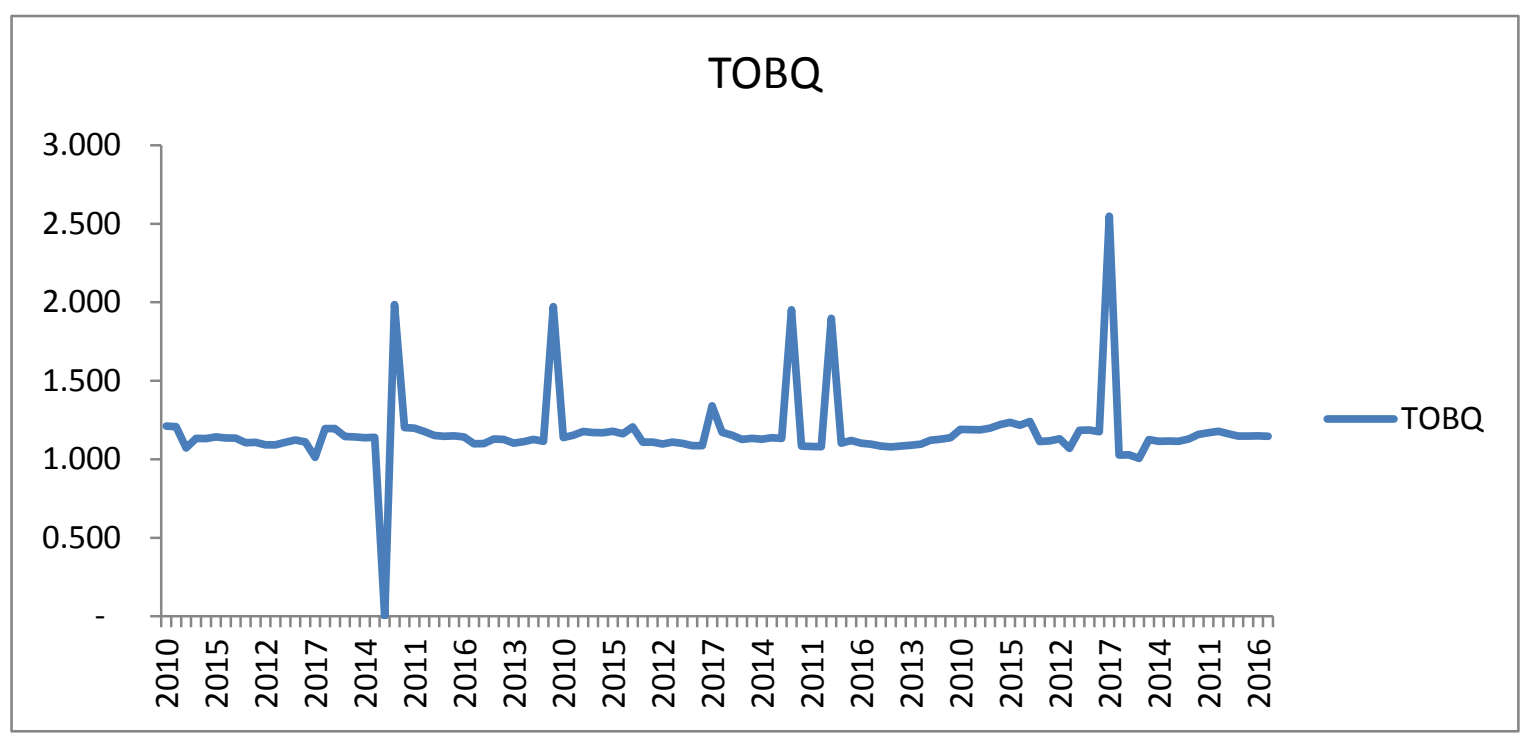

Figure 1. Trend analysis of Tobin Q

Interpretation: The Tobin Q analysis here shows a steady level for 4 years, then downward and upward (2014 then upward in 2011 then constant over three years and up in 2010. It remained steady over 4 years later up in 2014 and dropped and up again in 2016, stable for 5 years with the most significant rise in 2017 and calm in the same for 3 years just below Tobin Q average of 13 in the form of the bank's assets.

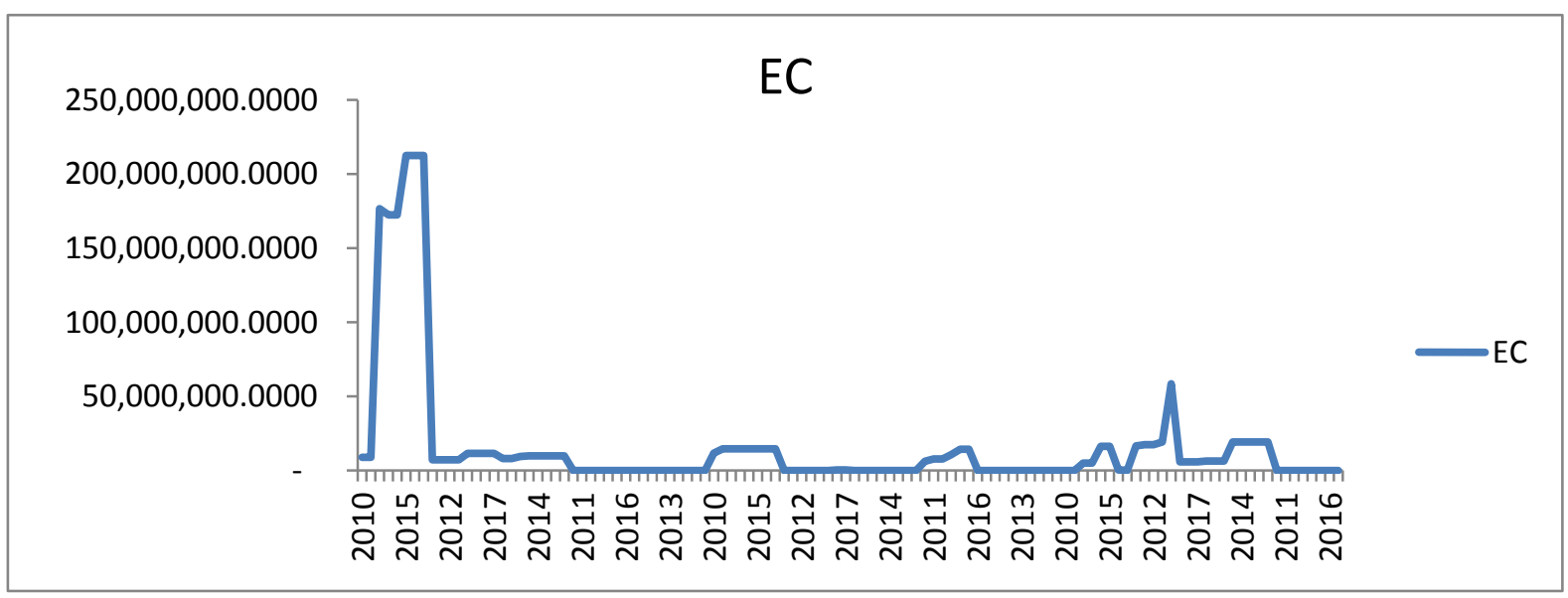

Figure 2. Trend analysis of Equity Capital (EC)

Interpretation: The equity capital fluctuates from 2010 to 2011, and it is not significant to expect from 2014 conscious grief. 


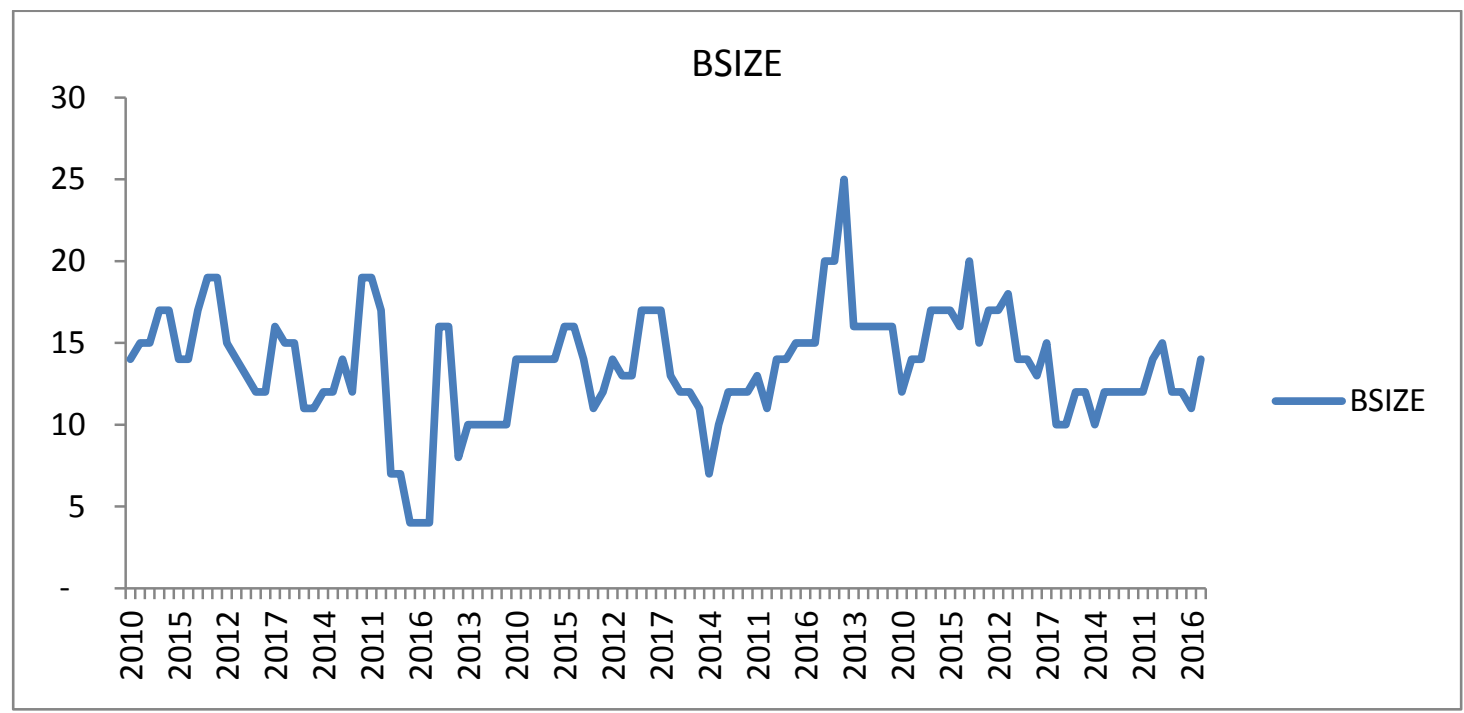

Figure 3. Trend analysis of Board Size (BSIZE)

Interpretation: Board Size fluctuated between 3 and 24 companies that were investigated in which most of the banks have a board size of between 7 to 17 directors on their board. A few of them have board size lower than seven members, and few have between 20 to 24, but on the average, most of the banks have board size (BSIZE) of 12 .

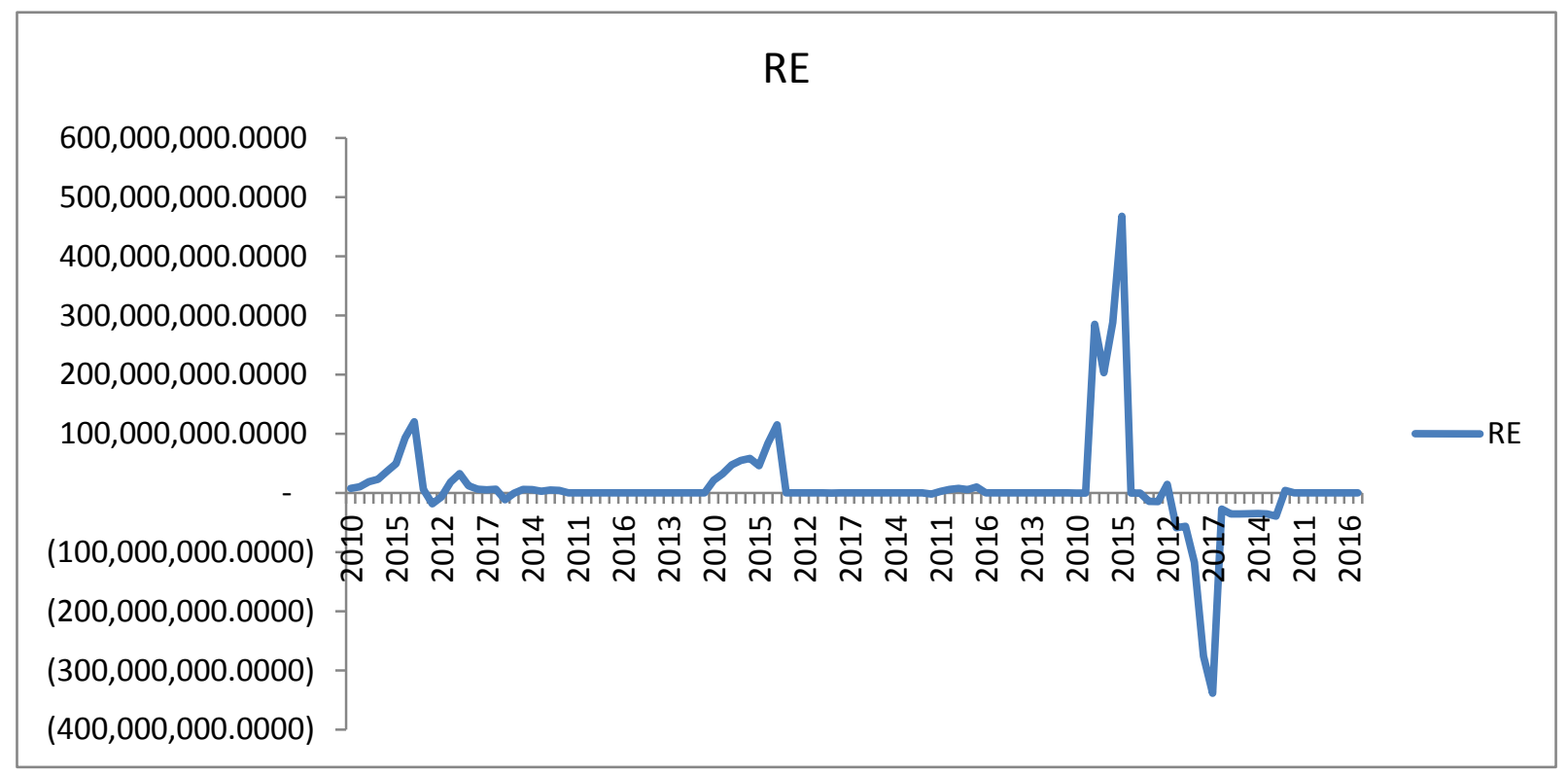

Figure 4. Trend analysis of Re-invested Earning (RE)

Interpretation: Re-invested earnings between 2010 to 2014 show a definite increase then it falls back to initiative financial value at once and stays stable minor oscillations. 


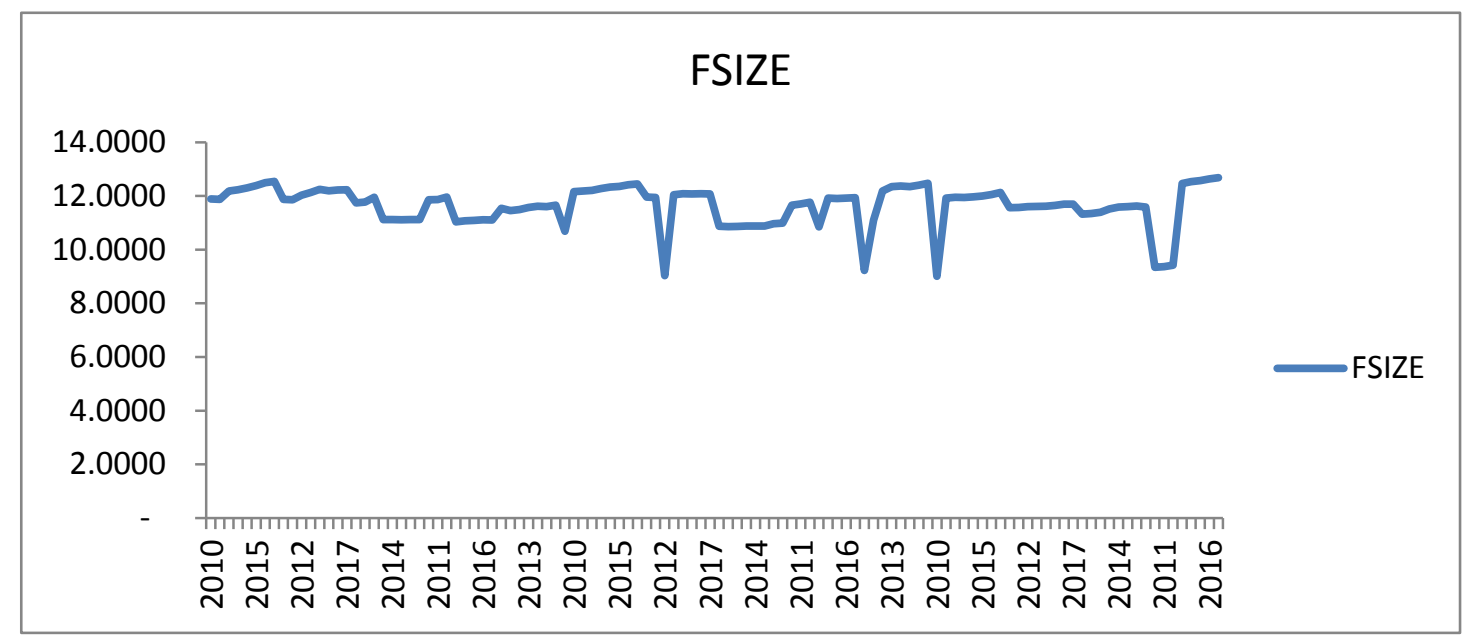

Figure 5. Trend analysis of Firm Size (FSIZE)

Interpretation: The firm sizes were on favourable position over the period from 2010 to 2015 but fluctuated in 2012 then study and down within three steps.

\subsection{Test for Stationarity}

The Unit Root Test (URT), is usually carried out to determine the stationary of the variables being employed in the research (Lawal, Babajide, Nwanji \& Eluyela, 2018; Popoola, Asalaye \& Eluyela, 2018). This study thus tests whether the panel data is stationary or not to avoid the risk of obtaining significant regressions results from unrelated data when non-stationary panel data are used in the regression analysis. Regressions are said to be spurious when its effect is obtained from irrelevant data. Two methods used in performing the unit root test are the Philips-Perron (PP) unit root test and the Augmented Dicker Fuller (ADF) unit root test (Falaye at al, 2019; Oladipo et al, 2019a). For this study, the Augmented Dicker Fuller and Philips- perron (PP) unit root test is employed to test the stationary of the variables.

Table 3. Stationarity test at level

\begin{tabular}{lll}
\hline ADF (Augmented Dicker Fuller) & \\
\hline Variables & Adf statistic & Comment \\
\hline TOBQ & 0.1100 & Non-stationary \\
\hline EC & $0.0003^{*}$ & Stationary \\
\hline RE & $0.0002^{*}$ & Stationary \\
\hline FSIZE & 0.1846 & Non-stationary \\
\hline BSIZE & $0.0060^{* *}$ & Stationary \\
\hline
\end{tabular}

Note: * shows that variables are significant @5\% probability level

** shows that variables are significant @ 10\% probability level

Source: Authors' computation, (2019).

The Table 3 above presents the unit-roots test of the dependent and independent variables. The results show that EC, RE and BSIZE passed the augmented Dickey-Fuller (ADF) test at a level while TOBQ and FSIZE did not pass the test at a level so it will be tested at first difference. In other words, EC, RE and Bsize are stationary at level. (EC means Equity Capital, while RE is Re-investment Earnings and BSIZE (Board Size). The test at the stable level shown on (table 3) above indicates that both Tobin Q or (TOBQ), and Firm Size or (FSIZE) came in at above 10\% significant, so must be retested at stationarity test at first difference shown in (table 4) below. 
Table 4. Stationarity test at first difference (unit roots test)

\begin{tabular}{llll}
\hline Primary Difference & & & \\
\hline Variables & ADF Satistic $I^{\text {st }}$ differnce & Order of integration & Comment \\
\hline TOBQ & 0.0157 & $1(1)$ & Stationary \\
\hline FSIZE & 0.0006 & $1(1)$ & Stationary \\
\hline
\end{tabular}

Source: Authors' computation (2019)

The Table 4 above presents the unit-roots test of the dependent and independent variables. The results show that EC, RE and BSIZE passed the augmented Dickey-Fuller (ADF) test at a level while TOBQ and FSIZE passed the test at first difference. The implication is that EC, RE and FSIZE are stationary at a level while TOBQ and BSIZE are stationary at first difference. EC, RE and BSIZE are I (0) while TOBQ and FSIZE are I (1). Most of the variables were stationary at level (EC, RE, BSIZE) (Yang, et al., 2019).

\subsection{Descriptive Statistics}

The Descriptive technique shows the summaries of the information for the number of variables and computes the systemized values (Oladipo et al, 2019b). The size of their mean can well order variables, or it is being selected. Table 5 below shows the descriptive statistics for each dependent variables and independent variables.

Table 5 below gives a detailed summary statistic of the variables used in the research, with a total of 111 observations analyzed. Financial performance in the Table 5 shows that the mean value of Tobin q for fourteen banks within the period is 1.177905 with the standard deviation of 0.207076 , thus implying a high degree of distribution. The coefficient of skewness and kurtosis are 4.52 and 24.79, respectively, thus showing that the distribution of financial performance (Tobin q) is positively skewed. The Jarque-Bera statistic has a calculated value of 2575.410 and a significant probability of 0.000 . Equity capital in table 4.3 shows that the mean value of EC for fourteen banks within the period 4.00E+08 with the standard deviation of 2.27E + 09, thus implying a high degree of dispersion. The coefficient of skewness and kurtosis are 6.48 and 45.02, respectively, thus showing that the distribution of equity capital is positively skewed.

The Jarque- Bera statistic has a calculated of 8946.793 and a significant probability of 0.000 . Re-invested earnings in Table 5 show that the mean value of RE for fourteen banks within the period 9595864 . With the standard deviation of 79649020, I am thus implying a high degree of dispersion. The coefficient of skewness and kurtosis are 1.46 and 18.07, respectively, thus showing that the distribution of equity capital is positively skewed. The Jarque-Bera statistic has a calculated 1090.821 and a significant probability of 0.000 .

Table 5. Descriptive statistics

\begin{tabular}{llllll}
\hline & TOBQ & EC & RE & FSIZE & BSIZE \\
\hline Mean & 1.177905 & $4.00 \mathrm{E}+08$ & 9595864. & 11.65031 & 13.66667 \\
\hline Median & 1.134000 & 5844669 & 47723.00 & 11.85730 & 14.00000 \\
\hline Maximum & 2.547500 & $1.63 \mathrm{E}+10$ & $4.68 \mathrm{E}+08$ & 12.68430 & 25.00000 \\
\hline Minimum & 1.005000 & 592.0000 & $-3.39 \mathrm{E}+08$ & 9.010700 & 4.000000 \\
\hline Std. Dev. & 0.207076 & $2.27 \mathrm{E}+09$ & 79649020 & 0.757336 & 3.393398 \\
\hline Skewness & 4.520394 & 6.481636 & 1.463626 & -1.681052 & -0.215061 \\
\hline Kurtosis & 24.79701 & 45.02850 & 18.07596 & 6.287664 & 4.289489 \\
\hline Jarque-Bera & 2575.410 & 8946.793 & 1090.821 & 102.2702 & 8.546009 \\
\hline Probability & 0.000000 & 0.000000 & 0.000000 & 0.000000 & 0.013940 \\
\hline Sum & 130.7474 & $4.44 \mathrm{E}+10$ & $1.07 \mathrm{E}+09$ & 1293.184 & 1517.000 \\
\hline Sum Sq. Dev. & 4.716874 & $5.66 \mathrm{E}+20$ & $6.98 \mathrm{E}+17$ & 63.09132 & 1266.667 \\
\hline Observations & 111 & 111 & 111 & 111 & 111 \\
\hline
\end{tabular}

Source: Authors' computation (2019) 
Table 6. Hausman test: (The Hausman test is used to test for correlation random effect)

Random Effects- Hausman Test

\section{Correlated Random Effects - Hausman Test}

Equation: Untitled

Test cross-section random effects

\begin{tabular}{llll}
\hline Test Summary & Chi-Sq. Statistic & Chi-Sq. d.f. & Prob. \\
\hline Cross-section random & 3.307678 & 4 & 0.5077
\end{tabular}

Source: Researchers' computation (2019)

Table 6 represents above the probability relevance of what panel regression model to be used under these particular rules: Accept the model if the probability is less than 5\% which is 0.05 that is fixed Effect model is significant and accept the model if the probability is higher than $5 \%$ which is 0.05 that is the random effect model. Moreover, the model that is used in this work is the random effect model, and the P-value is statistically significant because the Probability value is 0.5077 ; that is, it is more significant than 0.05 .

Tables 7. Random effect panel regression

\begin{tabular}{|c|c|c|c|c|}
\hline Variable & Coefficient & Std. Error & t-Statistic & Prob. \\
\hline $\mathbf{C}$ & 1.377782 & 0.335949 & 4.101162 & 0.0001 \\
\hline EC & $4.33 \mathrm{E}-11$ & $1.48 \mathrm{E}-11$ & 2.922225 & 0.0044 \\
\hline RE & $-1.81 \mathrm{E}-09$ & $4.59 \mathrm{E}-10$ & -3.952190 & 0.0002 \\
\hline BSIZE & 0.003157 & 0.007315 & 0.431584 & 0.6670 \\
\hline FSIZE & -0.020852 & 0.028645 & -0.727943 & 0.4685 \\
\hline R-squared & 0.238273 & \multicolumn{2}{|c|}{ Mean dependent var } & 1.177905 \\
\hline Adjusted R-squared & 0.099032 & \multicolumn{2}{|c|}{ S.D. dependent var } & 0.207076 \\
\hline S.E. of regression & 0.196556 & \multicolumn{2}{|c|}{ Akaike info criterion } & -0.268349 \\
\hline Sum squared resid & 3.592971 & \multicolumn{2}{|c|}{ Schwarz criterion } & 0.171034 \\
\hline Log-likelihood & 32.89339 & \multicolumn{2}{|c|}{ Hannan-Quinn criter. } & -0.090105 \\
\hline F-statistic & 1.711232 & \multicolumn{2}{|c|}{ Durbin-Watson stat } & 1.549380 \\
\hline Prob (F-statistic) & 0.054166 & & & \\
\hline
\end{tabular}

Source: authors' computation (2019)

Table 7 above shows the summary of the random effect model that is already tested as the proper model required calculating the variables. The R-squared stands as at $23 \%$ or $(0.238273)$ and the probability value of F-statistic (0.054166). However, the first assumption states that foreign direct investment has a positive effect on equity capital and it has a significant relationship, the result is shown in table (7) that t-statistics and probability value of (2.922 and 0.0044) just like (Ayanwale, 2007) stated that foreign direct investment has a positive effect on economic growth. Furthermore, the second assumption says that foreign direct investment has a negative impact on re-investment earnings, and it has a meaningful relationship because it has a positive probability. The result is shown in table (7) that t-statistics and probability values of (-3.952 and 0.0002), the result like (Macaulay, 2011) work which state that foreign direct investment has a negative effect but has a significant relationship with economic growth (Osinubi, and Amaghionyeodiwe, 2010; John, 2016).

\subsection{Testing of Hypothesis}

Hypothesis testing is used to examine the relationship that happens between foreign direct investments a performance. Two key testable hypotheses were formulated in chapter one of this study. We subject these 
propositions to empirical testing drawing from the results of our regression analysis. Using the regression analysis, we see the values of the coefficient and t-statistics value to check the hypothesis. The basis for decision rule is the significances of the t- statistics as represented by probability values using E- views

\subsubsection{Hypothesis (1)}

$\mathrm{H}_{0}$ : There is no meaningful relationship between reinvested foreign earnings and financial performance of deposit money banks in Nigeria.

$\mathrm{H}_{1}$ : There is a meaningful relationship between reinvested foreign earnings and financial performance of deposit money banks in Nigeria.

The result of the hypothesis: The result shown in tables (7) that Re-invested foreign earnings has a negative relationship with financial performance (TOBQ). The result of this model reveals that there is a meaningful relationship between RE and TOBQ since the probability, which is 0.0002 is less than 0.05 .

Decision: From the above analysis, Re-invested earning has a significant impact on financial performance; therefore, we accept the alternative hypothesis $\left(\mathrm{H}_{1}\right)$.

\subsubsection{Hypothesis (2)}

$\mathrm{H}_{0}$ : Foreign equity capital does not have a significant impact on financial performance of deposit money banks in Nigeria.

$\mathrm{H}_{1}$ : Foreign equity capital has a significant impact on financial performance of deposit money banks in Nigeria.

The result of a hypothesis: The result from the table (7) that foreign equity capital has a positive relationship on financial performance (TOBQ). The result of this mode shows that there is a meaningful relationship between RE and TOBQ since the probability, which is 0.0044 is less than 0.05 .

Decision: From the above analysis, the foreign equity capital has a significant impact on financial performance (TOBQ); therefore, we accept the null hypothesis $\left(\mathrm{H}_{0}\right)$.

\subsubsection{Hypothesis (3)}

H0: Board size does not have a significant impact on financial performance of deposit money banks in Nigeria?

H1: Board size has a significant impact on financial performance of deposit money banks in Nigeria?

Result of a hypothesis: The result from Table (7) shows that board size has a positive relationship on financial performance (TOBQ). The result of this mode shows that there is no meaningful relationship between BSIZE and TOBQ since the probability which is 0.6670 is higher than 0.05

Decision: From the above table, the BOARD SIZE has no significant impact on financial performance (TOBQ); therefore, we decline the null hypothesis and accept the alternative hypothesis.

\subsubsection{Hypothesis (4)}

$\mathrm{H}_{0}$ : There is no meaningful relationship between firm size and financial performance of deposit money banks in Nigeria?

$\mathrm{H}_{1}$ : There is a meaningful relationship between firm size and financial performance of deposit money banks in Nigeria?

Result of the hypothesis: The result from Table (7) shows that firm size has a negative effect on financial performance (TOBQ). The result of this mode shows that there is no meaningful relationship between FSIZE and TOBQ since the probability, which is 0.4685 is higher than 0.05 .

Decision: From the above analysis, the FIRM SIZE has no meaningful relationship with financial performance (TOBQ); therefore, we accept the alternative hypothesis.

\section{Summary of Findings}

This study examined foreign direct investment and financial performance. The result of this study has shown that relationships exist between foreign direct investment (Equity capital, Re-invested earnings, Board size and Firm size) and financial performance (Tobin q). The study revealed that there is a positive relationship between foreign direct investment and financial performance. The main aims of this study were to examine foreign direct investment its impact on the financial performance of listed deposit money banks in Nigeria. Data inform of the annual reports of listed deposits banks in Nigeria were used for this study. Five significant variables were used Tobin Q, equity capital, reinvested earnings, firm size, and board size (Iraya, and Sait, 2018). 
Theoretical findings: Three theories where considered which include pecking order theory, trade-off theory, and profit maximisation theory. The pecking order theory is one of the theories of foreign direct investment which is based on the notion that a bank should not only focus on profit-making but should also take into consideration on how to source for finance either by debt or equity. The pecking order theory state that funds are given by the retained earnings of the firm or organisation and then more information is given compared to the case of equity. The equity holder, in this case, will expect their investment to attract a higher rate of return, which leads the equity being more costly than the use of external funding. The marginal cost-marginal revenue method and the total cost-total revenue method is the profit maximisation theory used for marking investment decisions. The result of this study shows a positive relationship between FDI and profit maximisation. Trade-off theory understands the fact that corporations are financed partly with debt and equity. Debt and equity are used to balance the cost and benefit of the banks' understudy.

Empirical finding: The hypothesis (1) of this study found that reinvested foreign earnings have a positive effect on the financial performance, and thus, we rejected the null hypothesis, and accept the alternative hypothesis. Hypothesis (2) was focused on determining if foreign equity capital has a significant impact on financial performance. The result of the findings shows that foreign equity capital has a significant effect on the financial performance of these banks. Therefore, we accept the alternative hypothesis and reject the null hypothesis. In hypothesis (3), we found that board size has a significant effect on financial performance. The result shows that board size has a positive relationship with financial performance. Therefore, we reject the null hypothesis and accept the alternative. In hypothesis (4) we found that firm size has a significant impact on financial performance. Therefore, we reject the null hypothesis and accept the alternative explanation. (Barua et al., 2017)

\section{Conclusions and Recommendations}

The study concludes that foreign equity capital has a significant effect on bank performance in Nigeria. The study revealed that foreign equity capital has a substantial and adverse impact of the bank. The study also concludes that re-invested foreign earnings were having a significant effect on bank performance. Specifically, the study found that re-invested foreign earnings significant and negative affected the bank performance on equity capital.

Recommendations: Based on the findings of the study, the following suggestions are, however, made: The study found that there is an increase in foreign equity capital improves performance. The study recommends that in Nigeria deposit money, banks should look to increase their foreign equity capital to enhance their performance in terms of Tobin q. Therefore, the recommendation of the research is that deposit money banks based in Nigeria to use re-invested earnings to improve their financial performance.

Contribution to Knowledge: This Study contributes to our understanding of the impact of foreign direct investment in the financial performance of the banking sector in the Nigerian economy. Our study revalidates them that foreign direct investment has a positive effect on Nigeria economic. Most of the studies carried out on foreign direct investment, and financial performance focused on economic growth. In this study, we focused on the relationship between FDI and financial performance of the money deposit banks. This study has shown that the development of the Nigerian banking system from local banks to International banks was because of the investments in the banking system from foreign investors through foreign direct investment.

\section{References}

Adeniyi, O., Omisakin, O., Egwaikhide, F. O., \& Oyinlola, A. (2012). Foreign direct investment, economic growth and financial sector development in small open developing economies. Economic Analysis and Policy, 42(1), 105-127. https://doi.org/10.1016/S0313-5926(12)50008-1

Agosin, M., \& Mayer, R. (2000). Foreign Investment in Developing Countries, Does It Crowd in Domestic Investment. UNCTAD Discussion Paper No. 146.

Aguda, N. A., \& Oladoja, I. (2017, Jan.-Mar.). The Impact of Foreign Direct Investment on Economic Growth in Nigeria. International Journal of Business \& Law Research, 5(1), 52-60.

Ahmed, U., \& Omorose, O. (2016). Foreign Direct Investment and Economic Growth: Evidence from Nigeria. International Journal of Business and Social Science, 7(3).

Aigner, D. J., \& Smith, K. R. (2013). Safety Margins and Profit Maximization in the theory of the firm. Journal of Political Economy, 79(6), 1293-1301. https://doi.org/10.1086/259836

Ajayi, S. I. (2006). The determinant of Foreign Direct Investment in Africa: A Survey of Evidence. 
Ajibola, A., Isiaka, M., Ogunleye, O., \& Adeyemi, O. (2018). Foreign Direct Investment and Economic Growth in Nigeria Revisited: A Sector Level Analysis Nile JBE. Journal of Business and Economics, 10, 69-85.

Ajibola, A., Isiaka, M., Ogunleye, O., \& Oluwaseun Adeyemi, O. (2018). Foreign Direct Investment and Economic Growth in Nigeria Revisited: A Sector Level Analysis. Nile Journal of Business and Economics, (10), 69-85.

Akanegbu, B. N., \& Chizea, J. J. (2017). Foreign Direct Investment and Economic Growth in Nigeria: An Empirical Analysis. European Journal of Research in Social Sciences, 5(1), 11. Retrieved from www.idpublications.org

Akinlo, A. E. (2004). Foreign direct investment and growth in Nigeria: An empirical investigation. Journal of Policy Modeling, 26, 627-639. https://doi.org/10.1016/j.jpolmod.2004.04.011

Akintimehin, O. O., Eniola, A. A., Alabi, O. J., Eluyela, D. F., Okere, W., \& Ozordi, E. (2019). Social capital and its effect on business performance in the Nigeria informal sector. Heliyon, 5. https://doi.org/10.1016/j.heliyon.2019.e02024

Al-Iriani, M., \& Al-Shamsi, F. (2007). Foreign Direct Investment and Economic Growth in the GCC Countries: A Causality Investigation Using Heterogeneous Panel Analysis. Topics in Middle Eastern and African Economies, 9.

Aluko, S. A. (1961). Financing economic development in Nigeria. The Nigerian Journal of Economic and Social Studies, 3(1), 39-67.

Aminu, B., Mohammed, A., \& Tanko, M. (2015). The effect of board size and composition on the financial performance of banks in Nigeria. African Journal of Business Management, 9(16), 590-598. https://doi.org/10.5897/AJBM2015.7797

Amondi, E. (2017). Effect of foreign direct investment on the performance of the real estate sector in Kenya. Retrieved from http://erepository.uonbi.ac.ke/bitstream/handle/11295/99297/

Amos, A. (2016). The impact of foreign direct investment on banking sector performance in Ghana. Retrieved from http://hdl.handle.net/123456789/8495

Ananwude, A. C., Adigwe, P. K., Okaro, C. S., \& Emejulu, I. J. (2018). Banking Sector Operations and Foreign Direct Investment in Nigeria: A Causality Analysis. Asian Themes in Social Sciences Research, 1(2), 60-75. https://doi.org/10.18488/journal.139.2018.12.60.75

Anetor, F. (2019). Foreign Direct Investment Inflows and Real Sector: A Vector Autoregressive (var) Approach for The Nigerian Economy. The Journal of Developing Areas, 53(3), 27. https://doi.org/10.1353/jda.2019.0036

Asafo-Adjei, A. (2007). Foreign Direct Investment and its Importance to the Economy of South Africa. Unpublished Masters Project, University of South Africa.

Asaleye, A. J., Adama J. I., \& Ogunjobi, J. O. (2018). The financial sector and manufacturing sector performance: evidence from Nigeria. Investment Management and Financial Innovations, 15(3), 35-48. https://doi.org/10.21511/imfi.15(3).2018.03

Asogwa, F. O. (2014). The Impact of Foreign Direct Investment on Economic Growth in Nigeria. IOSR Journal of Economics and Finance (IOSR-JEF), 3(5), 37-45. https://doi.org/10.9790/5933-0353745

Ayanwale, B. A. (2007). FDI and Economic Growth: Evidence from Nigeria. AERC Research Paper 165, African Economic Research Consortium. Nairobi.

Ayanwale, B. A., \& Bamire A. S. (2001). The Influence of FDI on Firm-Level Productivity of Nigeria's Agro/Agro-Allied Sector. Final report presented to the African Economic Research Consortium, Nairobi.

Balsuburamanyan, V. N., \& Salisu, M. A. (2010). Foreign Direct Investment and Growth in EP and IS Countries. The Research Journal of Economics, 106, 92-105. https://doi.org/10.2307/2234933

Barua, S., Khan, T., \& Barua, B. (2017). Internationalisation and Performance: Evidence From Bangladeshi Banks. The Journal of Developing Areas, 51(2), 105. https://doi.org/10.1353/jda.2017.0034

Bebeji, A. Mohammed, A., \& Tanko, M. (2015). The effect of board size and composition on the financial performance of banks in Nigeria. African Journal of Business Management, 9(16), 590-598. https://doi.org/10.5897/AJBM2015.7797

Bello, A., \& Adeniyi, O. (2010). FDI and the Environment in Developing Economies: Evidence From Nigeria. Environmental Research Journal, 4(4), 291-297. https://doi.org/10.3923/erj.2010.291.297 
Bende-Nabende, A. (2002). Foreign Direct Investment Determinants in Sub-Sahara Africa: A Co-Integration Analysis. Economics Bulletin, 6(4), 1-19.

Bjorvatn, K. (2000). FDI in LDC: Facts, Theory and Empirical Evidence. LOS: Norwegian School of Economics and Business Administration and Norwegian Centre for Research in Organization and Management.

Bjorvatn, K., Kind, H. J., \& Nordås, H. K. (2002). The Role of FDI in Economic Development. Nordic Journal of Political Economy, 28, 109-126.

Blomström, M. (1986). Foreign Investment and Productive Efficiency: The Case of Mexico. Journal of Industrial Economics, 15, 97-110. https://doi.org/10.2307/2098609

Bloomstrom, M., Kokko, A., \& Mucchielli, J. L. (2003). The Economics of Foreign Direct Investment Incentives. Foreign Direct Investment in the Real and Financial Sector of Industrial Countries, 37-60. https://doi.org/10.1007/978-3-540-24736-4_3

Borensztein, E., De Gregorio, J., \& Lee, J. W. (1998). How does foreign direct investment affect economic growth?. Journal of International Economics, 45,115-135. https://doi.org/10.1016/S0022-1996(97)00033-0

Brown, C. V. (1962). External Economies and Economic Development. The Nigerian Journal of Economic and Social Studies, 4(1), 16-22.

CBN. (2007). Annual Economic Report. Central Bank of Nigeria.

CBN. (2010). Statistical Bulletin. Central Bank of Nigeria.

Chee, Y. L., \& Nair, M. (2010). The Impact of FDI and Financial Sector Development on Economic Growth: Empirical Evidence from Asia and Oceania. International Journal of Economics and Finance, 2(2), 107-119. https://doi.org/10.5539/ijef.v2n2p107

Childers, T. L., Carr, C. L., Peck, J., \& Carson, S. (2001). Hedonic and Utilitarian Motivations for Online Retail Shopping Behavior. Journal of Retailing, 77, 511-535. https://doi.org/10.1016/S0022-4359(01)00056-2

Chong, W., Neng, W., \& Yang, J. Q. (2013) Investment, Tobin's q, and Interest Rates. NBER Working Paper No. 19327. Retrieved from http://www.nber.org/papers/w19327

Choong, C.-K., Yusop, Z., \& Soo, S-C. (2004). Foreign Direct Investment, Economic Growth and Financial Sector Development: A Comparative Analysis. ASEAN Economic Bulletin, 21, 278-289. https://doi.org/10.1355/AE21-3B

Choong, C.-K., Yusop, Z., \& Soo, S-C. (2005). Foreign Direct Investment and Economic Growth in Malaysia: The Role of Domestic Financial Sector. Singapore Economic Review, 50, 245-268. https://doi.org/10.1142/S0217590805001998

Cyree, K., \& Morris, B. (2018). The effects of income and population demographics on a single county Bank performance. Journal of Economics \& Finance, 42(1), 174-190. https://doi.org/10.1007/s12197-017-9392-z

Danja, K. H. (2012). Foreign Direct Investment and the Nigerian Economy. American Journal of Economics, 2(3), 33-40. https://doi.org/10.5923/j.economics.20120203.02

Dasgupta, I. (2009). Supply Theory Profit Maximization. B.E. Journal of Theoretical Economics: Contributions to Theoretical Economics, 9(1), 1-14. https://doi.org/10.2202/1935-1704.1571

Desbordes, R., \& Wei, S. (2017). The Effect of Financial Development on Foreign Direct Investment. Journal of Development Economics, 127, 153-168. https://doi.org/10.1016/j.jdeveco.2017.02.008

Dornbusch, R., \& Edward, S. (1990). A three-gap model of foreign transfers and the GDP growth rate in developing countries. Journal of Development Economics, 32(2), 279-296. https://doi.org/10.1016/0304-3878(90)90039-E

Elar, S. J. (2018). The Effect of Inflation on Foreign Direct Investment in Kenya. Unpublished Masters Research Project in Finance, University of Nairobi.

Elhanan, H. (1984). A Simple Theory of International Trade with Multinational Corporations. Journal of Political Economy, 92(3), 451-471. https://doi.org/10.1086/261236

Eluyela, D. F., Adetula, D. T., Obasaju, O. B., Ozordi, E., Akintimehin, O., \& Popoola, O. (2019). Foreign directors, indigenous directors and dividend payout structure in Nigerian deposit money banks. Banks and Bank System, 14(2), 1-14. https://doi.org/10.21511/bbs.14(2).2019.16 
Eluyela, D. F., Akintimehin, O. O., Okere, W., Ozordi, E., Osuma, G. O., Ilogho, S. O., \& Oladipo, O. A. (2018a). Datasets for board meeting frequency and financial performance of Nigerian deposit money banks. Data in Brief. https://doi.org/10.1016/j.dib.2018.06.044

Eluyela, D. F., Akintimehin, O. O., Okere, W., Ozordi, E., Osuma, G. O., Ilogho, S. O., \& Oladipo, O. A. (2018b). Board meeting frequency and firm performance: examining the nexus in Nigerian deposit money banks. Heliyon, 4, 850. https://doi.org/10.1016/j.heliyon.2018

Falaye, A. J., Eseyin, O., Otekunrin, A., Asamu, F., Ogunlade, P., Egbide, B., ... Eluyela, D. (2019). Impact of exchange rate on manufacturing sector in Nigeria. International Journal of Mechanical Engineering and Technology, 10(2), 1568-1583. $\quad$ Retrieved from http://www.iaeme.com/ijmet/issues.asp?JType=IJMET\&VType=10\&IType=2

Feng, L. (2008, Nov 28). Does Foreign Direct Investment Harm the Host Country's Environment? Evidence from China. http:// doi.org/10.2139/ssrn.1479864

Festus, U. (2018). The Effect of Foreign Direct Investment on Economic Growth of Nigeria. International Journal of Arts, Languages and Business Studies (IJALBS), 1(1), 124-133.

Goldberg, L. S., \& Klein, M. W. (1998). Foreign Direct Investment, Trade and Real Exchange Rate Linkages in Developing Countries. In R. Glick (Ed.), Managing Capital Flows and Exchange Rates: Lessons from the Pacific Basin. Cambridge University Press. https://doi.org/10.3386/w6344

Goldberg, L. S., \& Klein, M. W. (1999). International Trade and Factor Mobility: An Empirical Investigation. https://doi.org/10.3386/w7196

Haggard, S. (1989). The Political Economy of Foreign Direct Investment in Latin America. Latin American Research Review, 24(1), 184-208. Retrieved from http://www.jstor.org/stable/2503287

Haruna-Danja, K. (2012). Foreign Direct Investment and the Nigerian Economy. American Journal of Economics. https://doi.org/10.5923/j.economics.20120203.02

Helpman, E. (1998). A Simple Theory of International Trade with Multinational Corporations. Journal of Political Economy, 92, 45-472.

Hennart, J. (1982). A theory of multinational corporations in world development. Ann Arbor: University of Michigan Press.

Hollis, C., \& Bruno, M. (1962). Development Alternatives in an Open Economy: The Case of Israel. Economic Journal, 57, 79-103. https://doi.org/10.2307/2228618

Hossain, M. I. (2015). Empirical Investigation of the Impact of Foreign. Asian Online Journal Publishing Group, 44-48.

Idoko, C. U., Idachaba, D., \& Agenyi, E. (2015). The Effects of Foreign Direct Investment in Sustainable Development in Nigeria. European Journal of Business and Management, 7(6).

Ikon, M. A., \& Chika, C. A. (2019). Organisational Identification and Employee Performance in Selected Commercial Banks in Delta State. European Journal of Business and Innovation Research, 7(4), 1-27.

Imoudu, E. C. (2012). The Impact of Foreign Direct Investment on Nigeria's Economic Growth: Evidence from the Johansen's Cointegration Approach. International Journal of Business and Social Science, 3(6), 122-13.

Iraya, C., \& Sait, K. (2018). The Effect of Investment in Technology on Lagged Stock Returns of Banks Listed at the Nairobi Securities Exchange. International Journal of Humanities and Social Science, 8, 137-143. https://doi.org/10.30845/ijhss.v8n5a15

John, E. I. (2016). Effect of Foreign Direct Investment on Economic Growth in Nigeria. European Business \& Management, 2(2), 40-46.

Jonida, L. (2015). Foreign Direct Investment in Banking System, Interdisciplinary. Journal of Research and Development, 2(1), 1-10.

Kariuki, A. K., \& Sang, P. (2018). Foreign Direct investment and bank performance in Kenya. Research Journal of Business and Management, 20(7), 10-20. https: ://doi.org/10.9790/487X-2007071020

King, R. F., Jackson, S. I., Katz, C. J., Mahler, V. A., \& Franz, M. G. (1986). The Impact of Taxes in Developed Capitalist Countries. The American Political Science Review, 80(1), 251-25. https://doi.org/10.2307/1957093 
Korna, J. M, Ajekwe, T., \& Idyu, I. A. (2013). The impact of foreign direct investment in the Nigerian Banking Sector. IORS Journal of Business and Management, 7(4), 77-92. https://doi.org/10.9790/487X-0747792

Lawal, A. I., Babajide, A. A., Nwanji, T. I., \& Eluyela, D. (2018). Are oil prices mean reverting? Evidence from unit root tests with sharp and smooth breaks. International Journal of Energy Economics and Policy, 8(6), 292-298. https://doi.org/10.32479/ijeep.6980

Luiz, R., \& Mello, D. (1999). Foreign Direct Investment-led Growth Evidence from Time and Panel Data. Oxford Economics Paper 51 (pp. 135-151), Oxford University Press. https://doi.org/10.1093/oep/51.1.133

Macaulay, E. D. (2011). Foreign Direct Investment and the Performance of the Nigerian Economy. Journal of Educational and Social Research, 1(5).

Mahalakshmi, S., Thiyagarajan, S., \& Naresh, G. (2016). Causal Links Between FDI Inflows and Macroeconomic Indicators of India. South Asian Journal of Management, 23(1), 112.

Mahler, V. A. (1989). Income Distribution within Nations: Problems of Cross-National Comparison. Comparative Political Studies (CPS), 22(1), 3-32. https://doi.org/10.1177/0010414089022001001

Markusen, J. R. (1984). Multinationals, multi-plant economies, and the gains from trade. Journal of International Economics, 16, 205-226. https://doi.org/10.1016/S0022-1996(84)80001-X

Markusen, J. R., \& Venables, A. J. (1998). Multinational firms and the new trade theory. Journal of International Economics, (46), 183-203. https://doi.org/10.1016/S0022-1996(97)00052-4

Modigliani, F., \& Miller, M. H. (1963). Corporate income taxes and the cost of capital: A correction. American Economic Review, 53, 433-43.

Muchugia, L. M. (2013). The Effect of Debt Financing on Firm Profitability of Commercial Banks in Kenya. Doctoral dissertation, University of Nairobi.

Mukolu, M. O., Otalu, J. A., \& Awosusi, C. T. (2013). Assessment of the Impacts of Foreign Direct Investment and Interest Rate on the Growth of the Nigerian Economy. IOSR Journal of Business and Management (IOSR-JBM), 15(3), 40-44. https://doi.org/10.9790/487X-1534044

Myers, S. C. (1977). Determinants of Capital Borrowing. Journal of Finance Economics, 5, 5147-5175. https://doi.org/10.1016/0304-405X(77)90015-0

Myers, S. C., \& Majluf, N. (1984). Corporate financing and investment decisions when firms have the information those investors do not have. Journal of Financial Economics, (13), 187-221. https://doi.org/10.1016/0304-405X(84)90023-0

Nunnemkamp, P., \& Spatz, J. (2004). Foreign direct investment and economic growth in developing economies: How relevant are host- economy and industry characteristics. Transnational Corporations, 13(3), 53-86.

Nwanji, T. I., \& Howell, K. E. (2007b). Shareholdership, Stakeholdership, and the Modern Global Business Environment: A Survey of the Literature. Journal of Interdisciplinary Economics, 18(4), 347-361. https://doi.org/10.1177/02601079X07001800406

Nwanji, T. I., Howell, K. E., Faye, S., Ogbu, U., Egbide, B. C., Eze, S. C., ... Boluwatife, A. (2019). The Effect of Board Composition and Financial Performance of Financial Services Firms in the Nigerian Stock Exchange Market. The International Journal of Business \& Management, 7(7).

O'Connor, Santos-Artega, F. J., \& Tavana, M. (2013). A game-theoretical model of bank foreign direct investment strategy in emerging market economies. International Journal of Bank Marketing, 32(3), 194-222. https://doi.org/10.1108/IJBM-08-2013-0077

Oji-Okoro, I., Huiping, H., Abubakar, A. S., \& Olufemi, E. A. (2014). FDI Trade and Its Effects on Agricultural. Development in Nigeria: Evidence from Time Series Analysis. International Journal of Management Science and Business Administration, 1(1), 28-40. https://doi.org/10.18775/ijmsba.1849-5664-5419.2014.11.1003

Okaro, C. S. (2016). Foreign Direct Investment (FDI) Inflows and Real Sector of the Nigerian Economy (2000-2015). Journal of Policy and Development Studies (IPDS), 10(4), 1597-9385. https://doi.org/10.12816/0041088

Okere, W., Eluyela, D. F., Lawal, A. I., Ibidunni, O., Eseyin, O., Popoola, O., \& Awe, T. (2019). Foreign Expatriates on Board and Financial Performance: A Study of Listed Deposit Money Banks in Nigeria. The Journal of Social Science Research, 5(2), 418-423. https://doi.org/10.32861/jssr.52.418.423 
Okonkwo, R. I., Egbunike, F. C., \& Udeh, F. N. P. (2015). Foreign Direct Investment and Economic Growth in Nigeria. Developing Country Studies, 5(9).

Olabisi, A., Jiboye, T., \& Akinyosoye, M. (2016). Efficacy of Vocational Training as an Integral Part of Entrepreneurship Education as a Transition Programme for Persons with Intellectual Disability in Oyo State. European Conference on Innovation and Entrepreneurship (p. 521).

Oladipo, O. A., Iyoha, O. F., Fakile, A. S., Asaleye, A. J., \& Eluyela, D. F. (2019a). Do government taxes have implication on manufacturing sector? Evidence from Nigeria. Journal of Management Information and Decision Sciences, 22(3), 181-190.

Oladipo, O. A., Iyoha, O. F., Fakile, A. S., Asaleye, A. J., \& Eluyela, D. F. (2019b). Tax revenue and agricultural performance: evidence from Nigeria. Problems and Perspectives in Management, 17(3), 342-349. http://doi.org/10.21511/ppm.17(3).2019.27

Olokoyo, F. O. (2012, April). Foreign direct investment and economic growth: a case of Nigeria. Bvimsr's Journal of Management Research, 4(1).

Olumuyiwa, O. S., \& Oluwatosin, O. F. (2012). An Econometric Analysis of Foreign Direct Investment on Economic Growth in Nigeria. IOSR Journal of Humanities and Social Science, 3(3), 31-39. https://doi.org/10.9790/0837-0333139

Onu, A. J. C. (2012). Impact of foreign direct investment on economic growth in Nigeria. Interdisciplinary Journal of Contemporary Research in Business, 4(5).

Onuorah, A. C., Nzotta, S. M., Ozurumba, B. A., \& Chigbu, E. E. (2015). Impact of Selected Economic Indicators on Foreign Investment Inflow in Nigeria and South Africa: Optimal Indicators Search. International Journal of Management Science and Business Administration, $1(7)$, 39-47. https://doi.org/10.18775/ijmsba.1849-5664-5419.2014.17.1004

Onyekwena, C. (2012). An empirical investigation of the impact of foreign direct investment on Manufacturing Firms and Banks in Nigeria.

Osinubi, T. S., \& Amaghionyeodiwe, I. A. (2010). Foreign Private Investment and Economic Growth in Nigeria. Applied Econometrics and International Development. Euro-American Association of Economic Development, 19(2).

Otekunrin, O. A., Nwanji, T. I., Agba, D. Z., Olowookere, J. K., Fakile, S. A., Ajayi, S. A., ... Oladiran, T. (2018). Outsourcing of accounting services and strategic cost management method (A case study of Dangote flour Plc and Doyin Investment Nig. Ltd). In Proceedings of the 32rd International Business Information Management Association Conference, Seville, Spain.

Otokiti, S. O. (2010). Contemporary Issues and Controversy in Research Methodology. Dubai: Dubai printing press.

Popoola, O., Asalaye, A. J., \& Eluyela, D. F. (2018). Domestic revenue mobilization and Agricultural productivity: evidence from Nigeria. Journal of Advanced Research in Law and Economics, 4(34), Summer, $1439-1450$. https://doi.org/10.14505//jarle.v9.4(34).31

Qureshi, M. A., Sheikh, N. A., \& Khan, A. A. (2015). A Revisit of pecking order theory versus trade-off Theory: Evidence from Pakistan. Pakistan Journal of Commerce \& Social Science, 9(2), 344-356.

Rafael, A., Maria, I., \& Pablo, P. (2017). Foreign direct investment and economic growth. Journal of Economic Analysis and Policy, 56, 176-187. https://doi.org/10.1016/j.eap.2017.09.006

Robert, M. (1957). International Trade and Factor Mobility. American Economic Review, 47, 321-335.

Rodolphe, D., \& Shang-Jin, W. (2017). The effect of financial development on foreign direct investment. Research Journal of Development Economics, 127, 153. https://doi.org/10.1016/j.jdeveco.2017.02.008

Saad, R. M. (2014). Effects of Equity and Debt Financing on SME Performance in Malaysia.

Saddimbah, G. (2014). Effect of Foreign Direct Investments (FDI) Inflow in Kenya on Economic Growth (GDP), Exports and Balance of Payment (Bop). Retrieved from http://erepo.usiu.ac.ke/

Salazar, L. A., Soto, C. R., \& Mosqueda, E. R. (2012). The Impact of Financing Decisions and Strategy on Small Business Competitiveness. Global Journal of Business Research, 6(2), 93-103. 
Singh, S., Tabassum, N., Darwish, K. T., \& Batsakis, G. (2017). Corporate Governance and Tobin's Q as a measure of Organisational Performance. British Journal of Management, 1-20. https://doi.org/10.1111/1467-8551.12237

The World Bank. (2016). Foreign Direct Investment Data Inflows.

Thirlwall, A. P. (1994). Growth and Development (5th ed.). London: McMillan. https://doi.org/10.1007/978-1-349-23195-9

Toulaboe, D., Terry, R., \& Johansen, T. (n.d.). Foreign Direct Investment and Economic Growth in Developing Countries. Southwestern Economic Review, 155-170.

Umar, U. O. (2017). The Impact of Capital Expenditure on Foreign Direct Investment in Nigeria. IOSR Journal of Humanities and Social Science (IOSR-J HSS), 22(11), 18-23.

Umaru, A., Gambo, E. J., \& Pate, H. A. (2015). Foreign Direct Investment and the growth of the Nigerian Economy. Journal of Economics and Development Studies, 3(1), 193-211. https://doi.org/10.15640/jeds.v3n1a10

Uwuigbe, U., Eluyela, D. F., Uwuigbe, O. R., Obakpro, T., \& Falola, I. (2018). Corporate governance and quality of financial statements: a study of listed Nigerian banks. Businees Perspective, 13(3), 12-23. https://doi.org/10.21511/bbs.13(3).2018.02

Wong, R. E. (2012). Profit Maximization and Alternative Theories: A Dynamic Reconciliation. American Economic Review, 65(4), 689-694.

Yang, T., Xiong, Z., \& Yang, C. (2019). Analysis of Exponential Stability for Neutral Stochastic Cohen-Grossberg Neural Networks with Mixed Delays. Discrete Dynamics in Nature and Society, 15. https://doi.org/10.1155/2019/4813103

Yusuf, M., Malarvizhi, C. A., Mazumder, M., \& Su, Z. (2014). Corruption, Poverty, and Economic Growth Relationship in the Nigerian Economy. The Journal of Developing Areas, 48(3), 95. https://doi.org/10.1353/jda.2014.0042 